\title{
Warmundus of Ivrea and episcopal attitudes to death, martyrdom and the millennium
}

\author{
by Gillian Mackie
}

Bishop, poet, patron of both architecture and the arts of the scriptorium, Warmundus of Ivrea stands out among the clerical figures of the Ottonian era for the breadth of his accomplishments in the arts and architecture, many of which survive to this day. In addition, both his own works and the historical sources record his political activities as an active opponent of the local lord, the Margrave Arduin.

His biography is anchored by a few securely recorded events, and can be filled in by a certain amount of speculation. His first appearance in the historical record dates from November 969, when, as bishop of Ivrea, he signed the decisions of the Synod of Milan in absentia. ${ }^{1}$ Ivrea was strategically important, as it lay on the route to Aosta and the mountain passes that linked Italy with the Ottonian lands north of the Alps. Pierre-Alain Mariaux has suggested, on convincing evidence, that Warmundus's consecration as bishop took place on Sunday, 7 March $966{ }^{2}$ His date of birth is not known, but was probably around $930 ;{ }^{3}$ the date of his death is also disputed, since he disappears from the record sometime between 1002 and $1006,{ }^{4}$ although some scholars have put his death as late as $1011 .^{5}$

1 This council was in session from 26 May to 17 October 969. For sources on the Council of Milan and information on Warmundus's participation, see P.-A. Mariaux, Warmond d'lvrée et ses images, politique et création iconographique autour de l'an mil (European University Studies 388) (Bem, 2002), 7.

2 Mariaux, Warmond d'Ivrée (above, n. 1), 10. His evidence for this is a note in an eleventh-century hand that adds the words 'consecratus e(st) warmund(us) ep[iscopus]' opposite the date 'Nonas marcii' in the calendar preface, fol. $2 \mathrm{v}$, of the ninth-century Martyrology of Adon of the Chapter Library of Ivrea (Ivrea, Bibl. Cap. cod. LVIII (39)). Mariaux's choice of date is based on the fact that bishops were always consecrated on Sundays. Since the only seventh of March (the nones) to fall on a Sunday in the period immediately before 969 occurred in 966, it seems likely that Warmundus was indeed consecrated in that year.

3 See G. Saroglia, Memorie storiche sulla chiesa d'Ivrea (Ivrea, 1881).

4 See A. Lucioni, 'Da Warmondo a Ogerio', in G. Cracco (ed.), Storia della chiesa di Ivrea, Ivrea dalle origini al XV secolo (Rome, 1998), 119-93, esp. pp. 137-9. See also Mariaux, Warmond d'Ivrée (above, n. 1), 40-1, n. 107, and 55, who has argued for a first day of August between 1002 and 1006 for his death.

5 A. Peroni, 'll ruolo della committenza vescovile alle soglie del mille: il caso di Warmondo di Ivrea', in Committenti e produzione artistico-letteraria nell'alto medioevo occidentale (Settimane di studio del Centro Italiano di Studi sull'Alto Medioevo XXXIX) (Spoleto, 1992), 243-74, esp. p. 246, with bibliography to 1975 on pp. 245-6 and in n. 3. 
It also is not known where Warmundus was educated, although Vercelli, Bologna and Pavia were suggested by Luigi Moreno, without firm evidence. ${ }^{6}$ Nor can it be determined securely that Warmundus was 'probably of German birth, appointed by the emperor (Otto I) to ensure Ivrea's allegiance to the Roman empire of the German nation', as Luigi Bettazzi asserted. ${ }^{7}$ However, it does seem possible, since his name, Warmund, translates as 'Mouth of 'Truth' in German, ${ }^{8}$ and is in frequent use north of the Alps. ${ }^{9}$

There are no solid, dated sources that refer to Warmundus during the subsequent three decades. However, a stone tablet of his era, built into the choir of the cathedral of Ivrea, records his rebuilding campaign, and such a major project must have occupied him for a large part of that time. ${ }^{10}$ Among the improvements of his era are tall twin bell-towers rising from a short transept, which fit into a pattern of such building in northern Italy in the late tenth century. ${ }^{11}$ Towers were needed to accommodate the new, larger bells that were responsible for 'signalling the hours of the divine offices'. ${ }^{2}$ Major work on the crypt and the ambulatory also took place at this time, very likely to serve the renewed interest of the era in the cult of the saints. When Warmundus does appear in the record again, it is in both the political sphere and in his role as an artistic patron. His dispute with his overlord Arduin, who had seized the Ivrea diocesan lands, was finally resolved by Emperor Otto III himself, ${ }^{13}$ while patronage now shows him commissioning books rather than architecture. ${ }^{14}$ The diocese of Ivrea had long been the site of a cathedral school, ${ }^{15}$ and its Chapter Library still owns a volume that dates back to the seventh

6 L. Moreno, Vita di San Veremondo Arborio, vescovo d'Ivrea nel secolo X (Ivrea, 1858), 9-11, suggested that Warmundus became a member of the Arborio family of Vercelli, adopting their sumame, and receiving his early education in letters and poetry there. He then studied canon law in either Bologna or Pavia. But see also Peroni, 'Il ruolo della committenza vescovile' (above, n. 5), 245. The lack of evidence has been discussed by Mariaux, Warmond d'turée (above, n. 1), 54, n. 136.

7 The Sacramentary exists in both a facsimile and an anastatic form, Sacramentarium Beati Warmundi. Sacramentario del Vescovo Warmondo di Ivrea, Ivrea (1990), which will be referred to here as Sacramentario. Bishop Luigi Bettazzi, bishop of Ivrea 1966-99, wrote an introduction to the anastatic version of the Sacramentary. For Bettazzi's assertion, see Sacramentario xxix.

8 I am indebted to Maria Abbott for this suggestion.

9 Mariaux, Warmond d'lyrée (above, n. 1), 54-5, n. 136.

10 Peroni, 'Il ruolo della committenza vescovile' (above, n. 5), esp. p. 265, and plate XIII, fig. 21. The text of this dedicatory epigraph runs + CONDIDIT HOC / DOMINO PRAE / SUL VVARMUN / DUS AB IMO. Mariaux has suggested that Warmundus probably decided to rebuild the cathedral between 980 and 990 , and entrusted the creation and decoration of new manuscripts for its altars to the scriptorium at the same time: Mariaux, Warmond d'Ivrée (above, n. 1), 246-7.

11 See C.B. McClendon, 'Church building in northern Italy around the year 1000 . A reappraisal', in N. Hiscock (ed.), The White Mantle of Churches (Turnhout, 2003), 221-32, esp. pp. 222-6 and fig. 138.

12 McClendon, 'Church building in northern Italy' (above, n. 11), 223.

13 Otto took up the cases of the bishops of Novara, Vercelli and Ivrea at Pavia in the spring of 1000 , and in a diploma dated 9 July of that year granted Bishop Warmundus rights over the episcopal city of Ivrea and its surroundings. See Peroni, 'Il ruolo della committenza vescovile' (above, n. 5), 246.

14 See Mariaux, Warmond d'Ivrée (above, n. 1), 31-2, for Arduin's actions against Warmundus, which culminated in his driving the bishop from his see. This remained vacant from 996 to 998 .

15 The bishops of Ivrea were granted the privilege of a local school by Lothair I in 825 . See L. Magnani, Le miniature del sacramentario d'Ivrea e di altri codici warmondiani (Vatican City, 1934), 17. 
century. ${ }^{16}$ The library's revival in the late tenth century is well documented because several codices that are attributed firmly to Warmundus in their dedications, and bear his name in their texts, have survived until today within its collection. ${ }^{17}$ Moreover, his likeness appears in several miniatures of the Warmundus Sacramentary (Ivrea, Bibl. Cap. cod. LXXXVI (39)), which also displays his poems in the frames surrounding its 62 miniatures. ${ }^{18}$ The content of these distichs identifies him as both an intellectual and an accomplished poet. ${ }^{19}$ Thus this bishop, whose tenure spanned the last third of the tenth century and lasted into the first few years of the eleventh, can be pictured as unusually gifted through his texts, portraits and poetry.

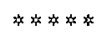

My intention is to use all these sources to visualize Warmundus as he was in the latter years of his life, the period of his patronage of the liturgical manuscripts now in the Ivrea Chapter Library. I shall explore the 'portraits' of him in his Sacramentary, and compare them with images of other bishops that occur in his manuscripts, outlining the iconography adopted for Warmundus. Reasons will also be advanced for his individualized appearance at some events and not at others. The choice of subjects to be illustrated in the Sacramentary will also be explored: which of the subjects of the 62 miniatures are shared with most other sacramentaries of the times and the cultural milieu, and which of them reflect Warmundus's own interests and preoccupations? Can we relate his choices to his life or to the broader environment of his times, and, if so, how? And to what extent does his poetry, which appears in the form of distichs or couplets in the frames of his miniatures, also reveal his concerns and, perhaps, his fears?

\section{WARMUNDUS AS AUTHOR}

\section{EVIDENCE FROM THE DEDICATIONS}

Warmundus dedicated his Sacramentary to the Virgin Mary in distichs within the frames that surround the texts of the Preface and Canon of the Mass. The frame around the text 'Per omnia saecula saeculorum' at the start of the Preface on folio l lv (FIG. 1), displays the first distich

16 Gregory the Great, Liber Regulae Pastoralis, Ivrea, Bibl. Cap. cod. I.

17 Biblioteca Capitolare, Ivrea: cod. IV (9), Ordo Missae, Prayers for the Bishop's Mass; cod. XVIII (8) and cod. XX (10), Benedictionals; cod. XXVI (12) and cod. XL (22), Gospel Books; and cod. LXXXV (30), a psalter. For particulars of the codices, see A. Professione (ed. I. Vignono), Inventario dei manoscritti della Biblioteca Capitolare di Ivrea (Alba, 1967), and, more recently, M. Ferrari and S. Gavinelli, 'Elenco dei codici della Biblioteca Capitolare di Ivrea', in Cracco (ed.), Storia della chiesa di Ivrea (above, n. 4), 975-89.

18 See Magnani, Le miniature del sacramentario d'Ivrea (above, n. 15), for a complete set of illustrations from the Sacramentary, together with a commentary, which is reprinted in the anastatic version.

19 His poems, including those in the Sacramentary, are collected in K. Strecker (ed.), Monumenta Germaniae Historica, Poetae Latini Medii Aevi V. Die Ottonienzeit (Munich, 1978-9), 458-63. 


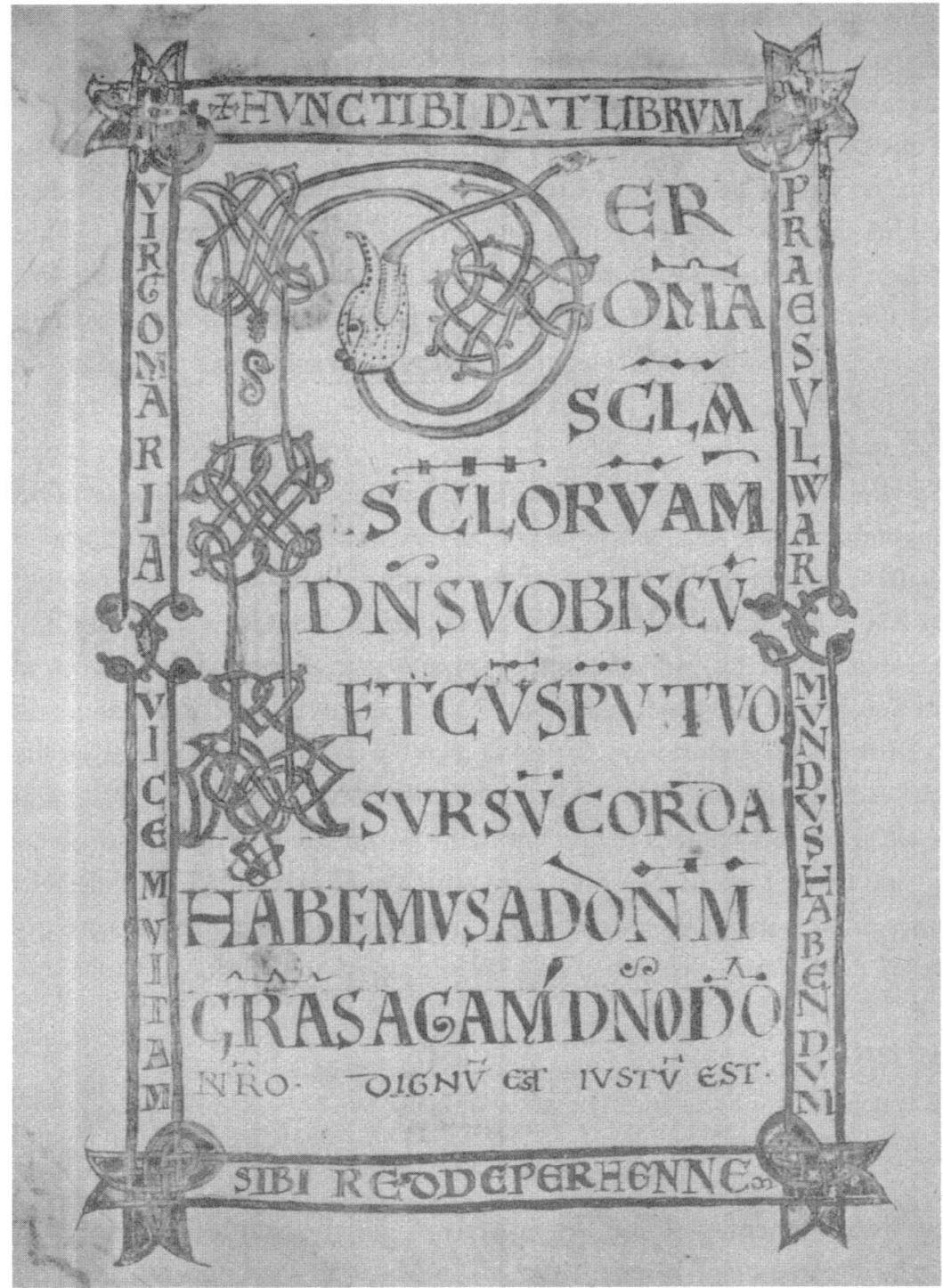

FIG. 1. Sacramentary of Warmundus, Ivrea, Bibl. Cap. cod. LXXXVI, fol. $11 \mathrm{v}$, 'Per omnia saecula saeculorum'. (Reproduced courtesy of the Biblioteca Capitolare di Ivrea.)

of the dedication: 'Prelate Warmundus gives you this book as yours, O Virgin Mary. Grant him in turn life eternal'. ${ }^{20}$ The dedication continues in the frames of folio 12 , both recto and verso. "This page maketh to shine the honour of the eternal king, may the recompense of His servant be the glory of the heavenly kingdom', and 'That Thou dost ever grant Thy servants great things for

20 H. Mayr-Harting, Ottonian Book Illumination (Oxford, 1991), II, 88, for the translation of HUNC TIBI DAT LIBRUM PRAESUL WARMUNDUS HABENDUM / VIRGO MARIA VICEM VITAM SIBI REDDE PERHENNEM. See Sacramentario (above, n. 7), 13, for the transcribed text. 
small, prepare for him that offers Thee these trifles the mighty spaces of Thy kingdom'. 21 The emphasis is on the exchange of gifts. The bishop hoped to receive the precious gift of heaven in return for his gift of a richly illuminated book, a sacramentary containing the liturgy as laid down for the use of a bishop at his high altar. Warmundus also dedicated his psalter (Ivrea, Biblioteca Capitolare, cod. LXXXV (30)) to the Virgin in the following words on folio $24 \mathrm{v}$ : 'O Virgin, Mother of God, Warmundus the prelate gives you the Book of Psalms as a gift, replete with a thousand fruits ... to him after death give life eternal', 22 and his Gospel Book (Ivrea, Bibl. Cap. cod. XXVI (12)) is dedicated to Mary on folios $1 v$ and 2 in these words: 'SUME DEI GENETRIX DONA FIDELIS PRESULIS ECCE TUI' (Accept, O Mother of God, the gift of your faithful prelate'). Since the cathedral was also dedicated to Mary, the continuity between the dedications is clear: the reconstruction work at the cathedral was to culminate in a set of new books for its high altar. Clearly Warmundus is represented as having a deep personal devotion to the Virgin, as Mariaux has emphasized. ${ }^{23}$

\section{EVIDENCE FROM THE IMAGES OF WARMUNDUS: CAN THEY BE SEEN AS PORTRAITS?}

An image of Warmundus, identified by a square 'halo', and clothed as for Mass, adorns folio 13, the 'Te igitur' page, at the start of the Canon of the Mass (FIG. 2). Here he wears a pallium, the symbol of a metropolitan bishop's rank. The crosses on it are depicted in deep red, with ornament, on a white ground. His arms are extended in prayer, and his head is framed by the square 'halo', which is painted gold and edged on all three sides in red. Scallops across the top possibly may imitate draperies, or even an article of clothing, the amice. ${ }^{24}$ The text above Warmundus's head reads 'Clothe with the gift of heavenly devotion, O Christ, the mind of him who has striven to bring you (the fruits of ) his labour'. ${ }^{25}$ Thus Warmundus identified himself as the working patron and begged Christ to give him heavenly devotion in return for his gift. We

21 AC DECUS AETERNI FULGESCIT PAGINA REGIS SIT MERCES SERVI CANALIS GLORIA REGNI (fol. 12r) and GRANDIA PRO PARVIS QUI NOSTRI REDDERE SERVIS HAEC TIBI PREBENTI CONFER SUBLIMACAELI (fol. 12v). Texts and translations from Sacramentario (above, n. 7), pp. xxix-xxx.

22 PSALTERII LIBRU(M) MILLENA FRUGE REFERTUM VIRGO D(E)I GENITRIX DONUM TU SUME FIDELIS DAT TIBI WARMUNDUS PRESUL PRO MUNERE MUNUS ET SIBI POST MORTEM VITA(M) CONCEDE PERHENNUM. Mayr-Harting, Ottonian Book Illumination (above, n. 20), II, 87-8, conflated the text from the frame of fol. $11 \mathrm{v}$ with the miniature of fol. $52 \mathrm{v}$, which is illustrated. He also erred in describing the Psalter, cod. LXXXV, as having no specific mention of Warmundus, ignoring the dedication on fol. 24v. Detailed specifications of all Warmundus's manuscripts can be found in P.-A. Mariaux, 'Entre la sceptre et la crosse' - Portrait d'un évêque du Xe siècle (Ph.D. thesis, Lausanne, 1997).

23 Mariaux, Warmond d'Ivrée (above, n. 1), esp. ch. 4, 'Beatae Dei Genetricis servus'.

24 Evan Gatti has suggested that this 'square halo' in fact represents an amice, a 'square of white linen worn by the celebrant priest, formerly on the head and now on the shoulders'. See her Developing an Iconography of the Episcopy: Liturgical Portraiture and Episcopal Politics in Late-tenth-and Early-eleventhcentury Manuscripts (Ph.D. thesis, University of North Carolina at Chapel Hill, 2005), 104. I thank her for sharing her work on Warmundus with me. For amice, see Oxford Concise Dictionary (Oxford, 1964), 38.

25 Mayr-Harting, Ottonian Book Illumination (above, n. 20), II, 88, translation of +MENTEM DEVOTI CAE / [LE]STI MUNERE VESTI /, CHRISTE TIBI TALEM STUDUIT / QUI FERRE LABOREM. 


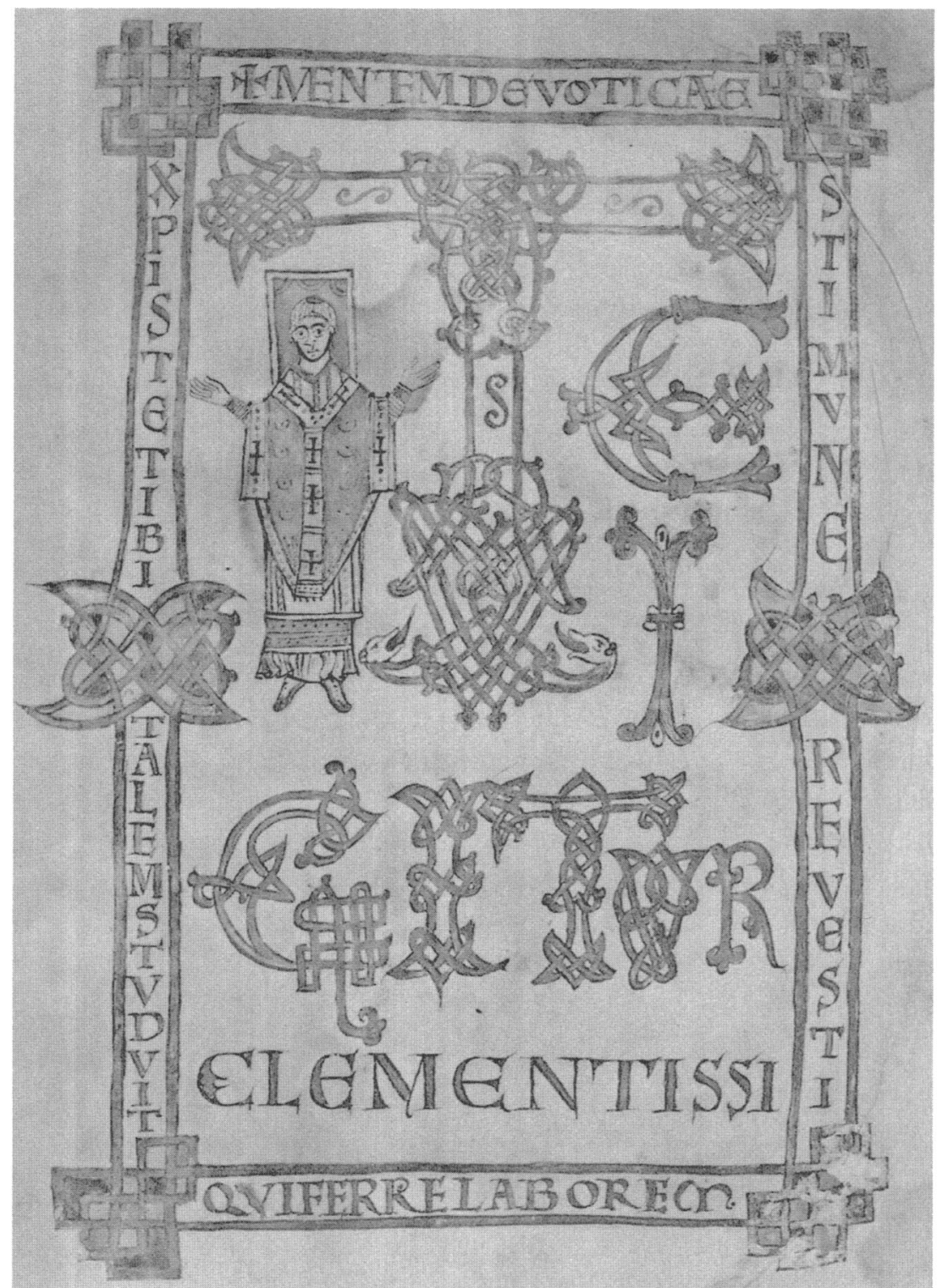

FIG. 2. Sacramentary of Warmundus, Ivrea, Bibl. Cap. cod. LXXXVI, fol. 13, 'Te igitur'. (Reproduced courtesy of the Biblioteca Capitolare di Ivrea.)

see here an active man, with a love of art and of language, who is also a dedicated Christian, mindful of the need of faith that can come only as a gift from Christ himself. This is the first of three 'portraits' of Warmundus, and the question arises: do they attempt a faithful likeness of the bishop?

The vital clue resides in the square 'halo', and the evidence comes from Rome, where the use of the square 'nimbus' was relatively common in the eighth and ninth centuries. Images of papal 


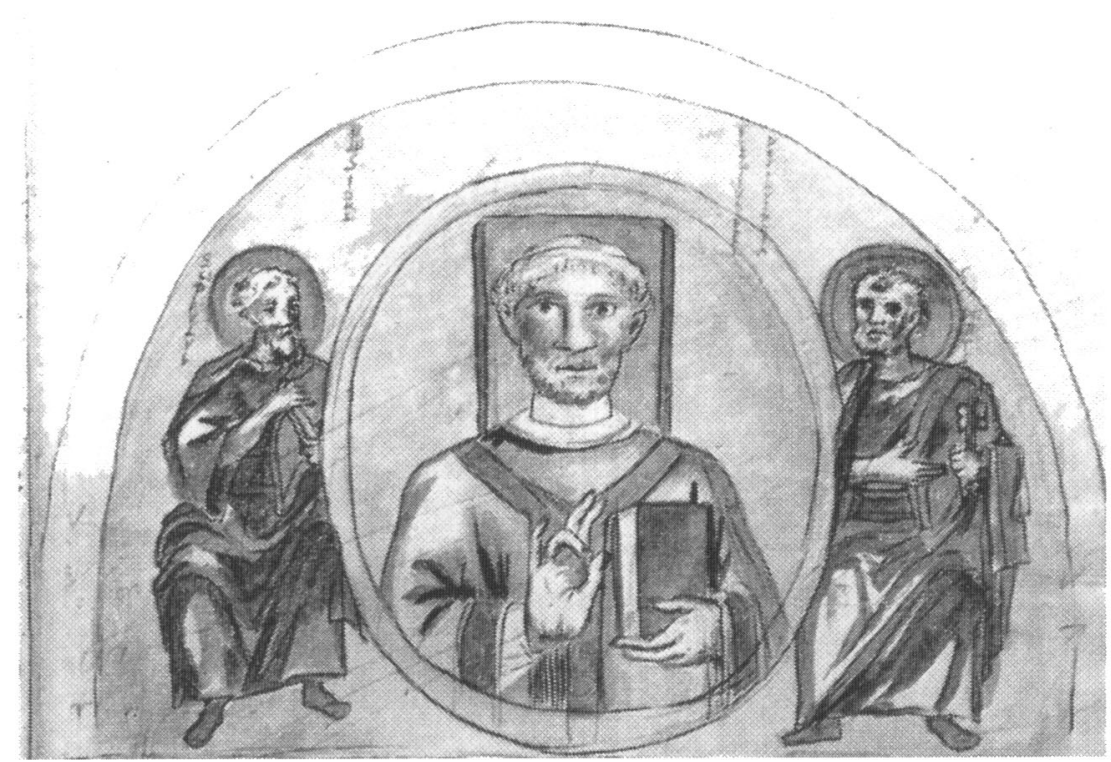

FIG. 3. Pope John XIII (965-72), watercolour after a lost painting from San Paolo fuori le mura, Rome. (From S. Waetzoldt, Die Kopien des 17. Jahrhunderts nach Mosaiken und Wandmalereien in Rom (Vienna, 1964), fig. 326, after Biblioteca Apostolica Vaticana, Barb. lat. 4406, fol. 141.)

donors were identified by this attribute both in the mosaics and paintings that they commissioned and in their funerary portraits. John Osborne has drawn attention to a text from John the Deacon's late ninth-century Life of Gregory the Great that throws light on the question of whether a square 'nimbus' indicates a portrait. ${ }^{26}$ John the Deacon described the square 'halo' that surrounded a portrait of Pope Gregory I (c. 540-604) in the monastery that he had built on his family property in Rome. He gave a contemporary, ninth-century interpretation of this now-lost sixth-century painting, and stated that the 'nimbus', far from being a halo, identified the painting as an actual likeness of the pope. Although a further century elapsed before Warmundus's Sacramentary appeared, together with its images of the bishop, two of which were defined by a square 'nimbus', the motif was in use throughout Italy during the intervening period. In Rome, the lost funerary portraits of two popes, John XIII (965-72) (FIG. 3), and, probably, John XVIII (1004-9), from San Paolo fuori le mura, are known from seventeenth-century

26 J. Osborne, 'The portrait of Pope Leo IV in San Clemente, Rome: a re-examination of the so-called 'square' nimbus, in medieval art', Papers of the British School at Rome 47 (1979), 58-65, esp. pp. 63-4, and n. 37 for John the Deacon's text in S. Gregorii Magni Vita iv, 84 (Migne, PL 75, col. 231). Osborne suggested that the definition of the sides of the 'square' represents an attempt to depict a three-dimensional wooden panel. Gerhart Ladner suggested that the square halo may have been a later addition to the Pope Gregory portrait: see his 'The socalled square nimbus', Medieval Studies 3 (1941), 15-45, at p. 17, but this does not invalidate John the Deacon's point, namely that at his time it indicated a portrait of a living person. 
watercolour copies in the Vatican Library. ${ }^{27}$ Both included the square 'nimbus'. This motif was also used well into the tenth century in manuscript art: in Montecassino cod. 175, Paulus Diaconus, Commentarius in Regulam S. Benedicti, a miniature of Abbot John of Monte Cassino-Capua (915-34) is shown, complete with a square 'halo', presenting the codex to Saint Benedict. ${ }^{28}$ Myrtilla Avery collected numerous other examples from Exultet Rolls made in the late ninth and tenth centuries in southern Italy. Osborne also made a convincing case for the square 'nimbus' as an indication that a portrait was intended. ${ }^{29}$

\section{The iconography of the Bishops portrayed in the Warmundus SaCramentary}

The features given to Warmundus in the Sacramentary plainly distinguish him from the other bishops portrayed in that codex, and are best shown in the larger image of folio 52v (FIG. 4), though he appears with similar features in the smaller 'Te igitur' and Crucifixion miniatures (fols 13 and 57v; FIGs 2 and 5). His hair is shown as straight and dark, receding on either side of a central 'widow's peak'. He is tonsured, and his ears are exposed. He has a distinctive short chin, a straight nose, and a benign and thoughtful expression. His chin is defined by a slight crease below which his neck sags. His eyes are emphasized by arched eyebrows, and bags beneath them may be signs of poor health and advancing age. These features distinguish him from the bishops of folio 2, the Crowning of a King (FIG. 6), and folio 8, the Consecration of a Bishop (FIG. 7). These are shown as youthful figures, with full rounded chins and with light-coloured hair that is parted at the side, and full and wavy over the ears and around the tonsure. The single older bishop in the consecration scene is bearded, and has long hair and a long face, unlike Warmundus. Only the image of Gregory I, shown in the frontispiece, folio 8v (FIG. 8) comes close to the Warmundian iconography. Perhaps this is not coincidental.

The clearest likeness of Warmundus is that on folio $52 \mathrm{v}$, where he is shown at the altar (FIG. 4). His square 'halo' is of a simpler type here, with neither 'scallops' nor side panels. It is drawn in slight perspective, as Warmundus turns in three-quarter view. He is blessing the chrism in preparation for the forthcoming Easter baptisms. He is again clad in pontificals, including a pallium, but he is shown here with green hair and a red halo, arbitrary colours that are typical of the Sacramentary. ${ }^{30}$ He officiates at a decorated altar, which richly imitates an original in

27 Biblioteca Vaticana, Barb. Lat. 4406, fols 14lr and 142r. See S. Waetzoldt, Die Kopien des 17. Jahrhunderts nach Mosaiken und Wandmalereien in Rom (Vienna, 1964), plates 326, 327; and Ladner, "The so-called square nimbus' (above, n. 26), nos. 20, 21.

28 Ladner, 'The so-called square nimbus' (above, n. 26), 38, no. 33. See also M. Avery, The Exultet Rolls of South Italy (Princeton, 1936), pl. cxcvi; J. Osborne, 'The painting of the Anastasis in the lower church of San Clemente, Rome: a re-examination of the evidence for the location of the tomb of St. Cyril', Byzantion 51 (1981), 255-87, esp. pp. $270-2$.

29 See Osborne, “The painting of the Anastasis' (above, n. 28), 269-72.

30 See Mariaux, Warmond d'lvrée (above, n. 1), 75: 'La mise en couleurs a lieu ensuite, et de manière totalement arbitraire ... car la couleur, loin d'énrichir le dessin, le dènature: des cheveux verts, des barbes rouges ou bleues sont lëgion, alors que la palette disposition permet une mise en couleurs un peu plus 'rèaliste'. See also his Annexe, 24l-2 and 246, where he has suggested that the colour was applied by a later and less skilled hand than did the drawing itself, and referred to this artist's 'anarchic application' of colour as confusing the vision of the drawing. 


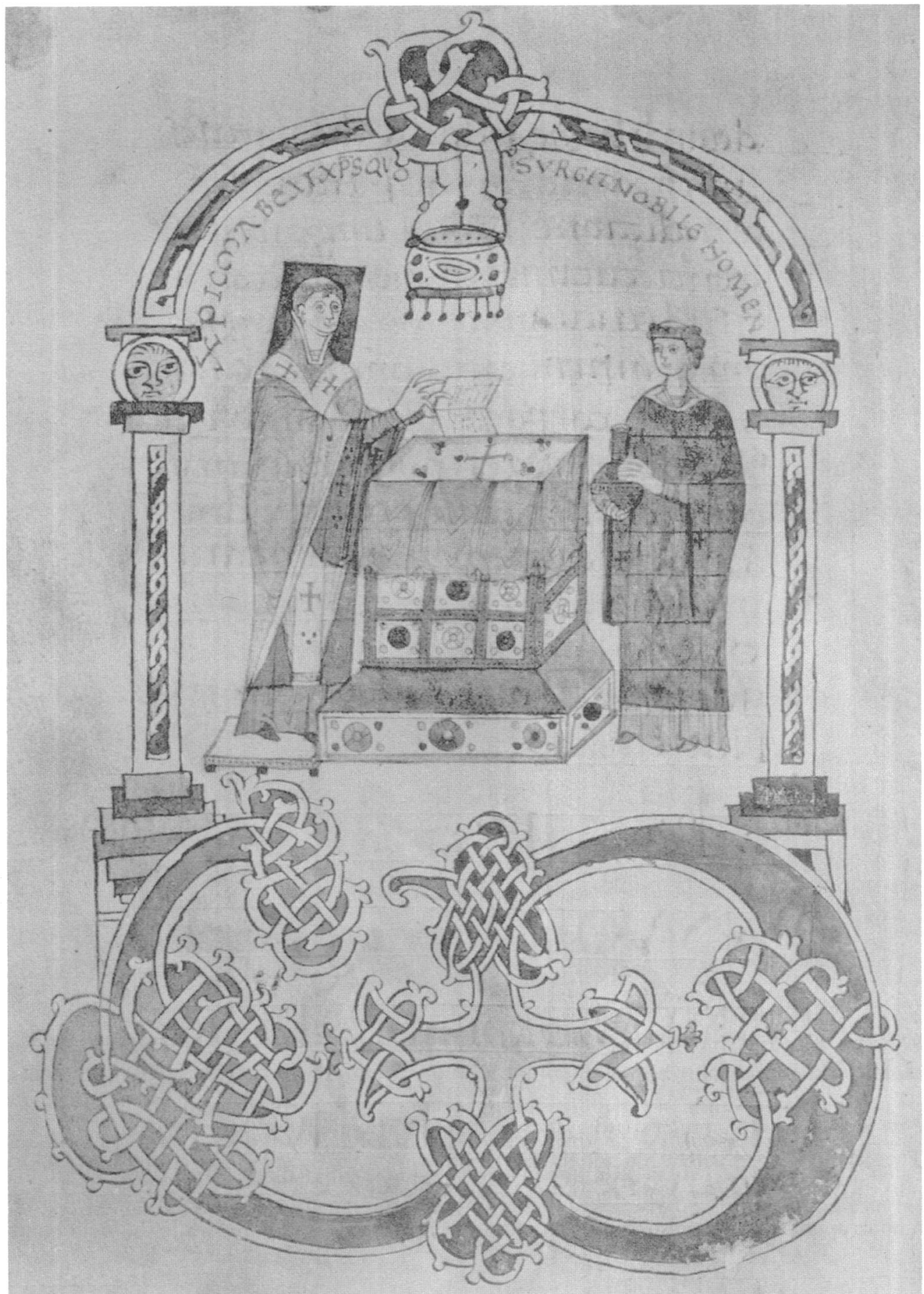

Fig. 4. Sacramentary of Warmundus, lvrea, Bibl. Cap. cod. LXXXVI, fol. 52v, Blessing the Chrism. (Reproduced courtesy of the Biblioteca Capitolare di Ivrea.) 


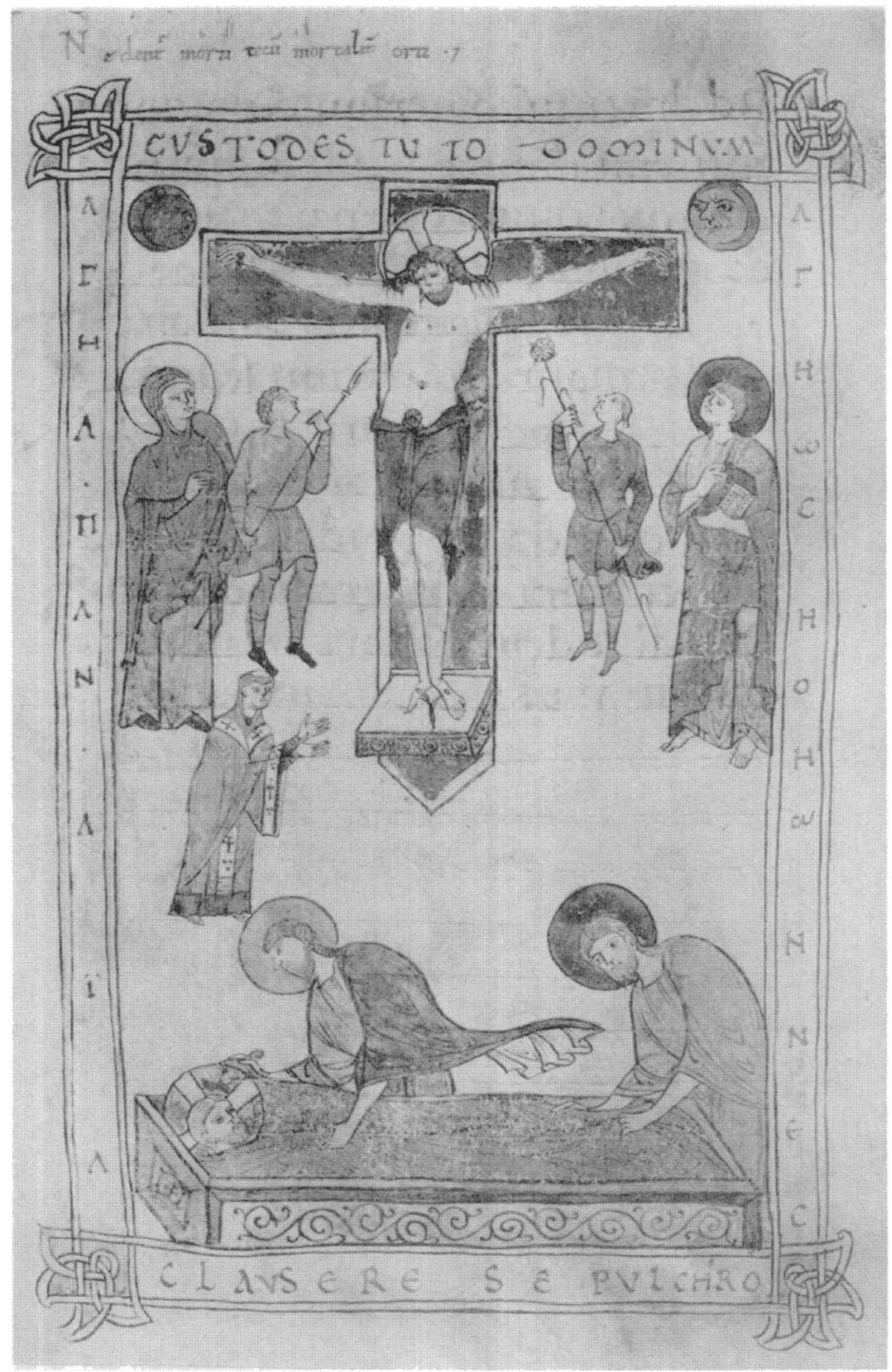

Fig. 5. Sacramentary of Warmundus, Ivrea, Bibl. Cap. cod.

LXXXVI, fol. $57 \mathrm{v}$, Crucifixion of Christ. (Reproduced courtesy of the Biblioteca Capitolare di Ivrea.)

opus sectile, where circular marble discs in red, yellow and green were set in square frames. ${ }^{31}$ The altar is draped with a blue cloth and topped with a cross, and a deacon holds the flask of oil to be blessed. The precise moment is marked by the bishop's gestures: the left hand holds a book open at a text, presumably that of the liturgy for this ceremony, while the right hand is

31 See B. Baroffo and F. Dell'Oro, 'L'Ordo Missae' del Vescovo Warmondo d'Ivrea', Studi Medievali 16 (2) (1975) , 795-823, for identification of a similar Warmundian altar in the Ordo as typical of the Rhine area. That altar is illustrated on folio 4v of the Ordo Missae, cod. IV (9) (FIG. 9). 


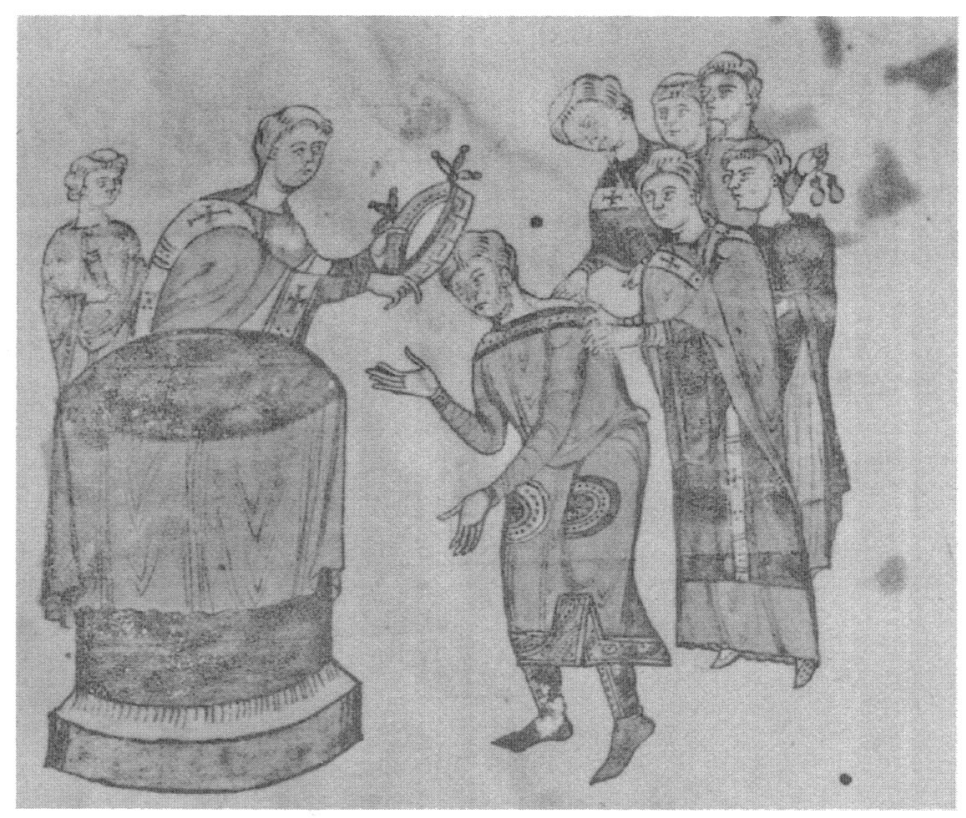

FIG. 6. Sacramentary of Warmundus, Ivrea, Bibl. Cap. cod. LXXXVI, fol. 2, Crowning of a King. (Reproduced courtesy of the Biblioteca Capitolare di Ivrea.)

raised to bless. ${ }^{32} \mathrm{He}$ is firmly identified as Warmundus by the square 'halo', and as Christ's representative by the inscription on the arch above his head 'CHRISMA BEAT CHRISTUS QUO SURGIT NOBILE NOMEN' ('(It is) Christ who blesses the sacred oils raised in his name').

This miniature shows Warmundus in his role as bishop, carrying out a duty reserved only for bishops and archbishops. So on one level the miniature can be understood as a straightforward rendering of an annual liturgical event, which by its very nature defines the book's user as a bishop. On another plane, by depicting this bishop as Warmundus and giving him the square halo and individualized features, the scribe recorded the fact that Warmundus, as diocesan bishop, had indeed officiated at this ceremony himself. It was one of the many responsibilities that his position entailed, and that he fulfilled faithfully, in the pastoral sphere, the building programme and the scriptorium. In return, he received the privileges and honours of his rank.

As noted above, Warmundus appears in person also in another miniature, folio $57 \mathrm{v}$ (FIG. 5). Here the Crucifixion of Christ is depicted in the upper register, with the entombment below. Both the cross and Christ's halo in the tomb are shown in unbroken gold. The standard personae appear around him. They include the sorrowing Virgin on Christ's right, and Saint John on his

32 Commonly given to bishops, this blessing gesture is well illustrated by the sixth-century image of Archbishop Ursicinus in the apse of Sant'Apollinare in Classe, Ravenna. See F.W. Deichmann, Ravenna. Haupstadt des Spätantiken Abendlandes, 4 vols (Wiesbaden, 1969-1989), III, plate 394. 


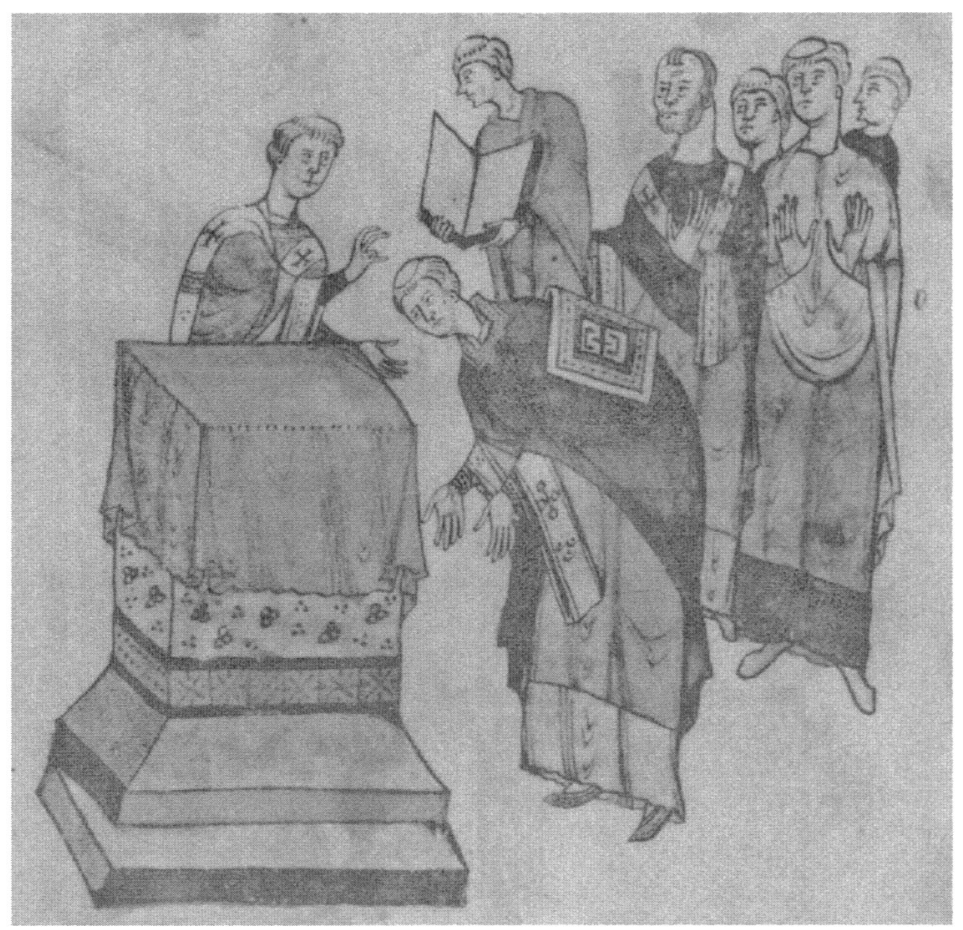

FIG. 7. Sacramentary of Warmundus, Ivrea, Bibl. Cap. cod. LXXXVI, fol. 8, Consecration of a Bishop. (Reproduced courtesy of the Biblioteca Capitolare di Ivrea.)

left. The soldiers, Longinus with the spear and his companion Stephaton with the sponge dipped in vinegar, are present, as are the sun and moon, indicating 'the sorrow of all creation at the death of Christ'. ${ }^{33}$ Warmundus stands at a lower level, and his figure is the smallest in the hierarchy of size. He is dressed in blue with red borders, his hair is also blue, in contrast to the green hair of folio $52 \mathrm{v}$, the Blessing of the Chrism. He can be recognized by his features as well as his vestments, but lacks the square 'halo' of the other portraits. Is there simply no room, as Mariaux suggested $?^{34}$ Or is it because Warmundus was not literally present at the Crucifixion? Does this tiny portrait express Warmundus's personal devotion to the Virgin, below whom he stands, as well as the dignity of the episcopal office he represents? Is it significant that he gestures with both hands towards the blood that flows from Christ's feet? ${ }^{35}$ He is both donor and witness, and one can ask whether he should be compared with the Ottonian royal donors discussed by Robert Deshman. ${ }^{36}$ Certainly Warmundus's simple gesture is in marked contrast

33 G. Ferguson, Signs and Symbols in Christian Art (Oxford, 1954; repr. 1977), 45.

34 Mariaux, 'Entre la sceptre et la crosse' (above, n. 22), 133.

35 I thank Joseph Polzer for this suggestion.

36 R. Deshman, "The exalted servant: the ruler theology of the prayerbook of Charles the Bald', Viator 11 (1980), 385-417, esp. pp. 387-94. 


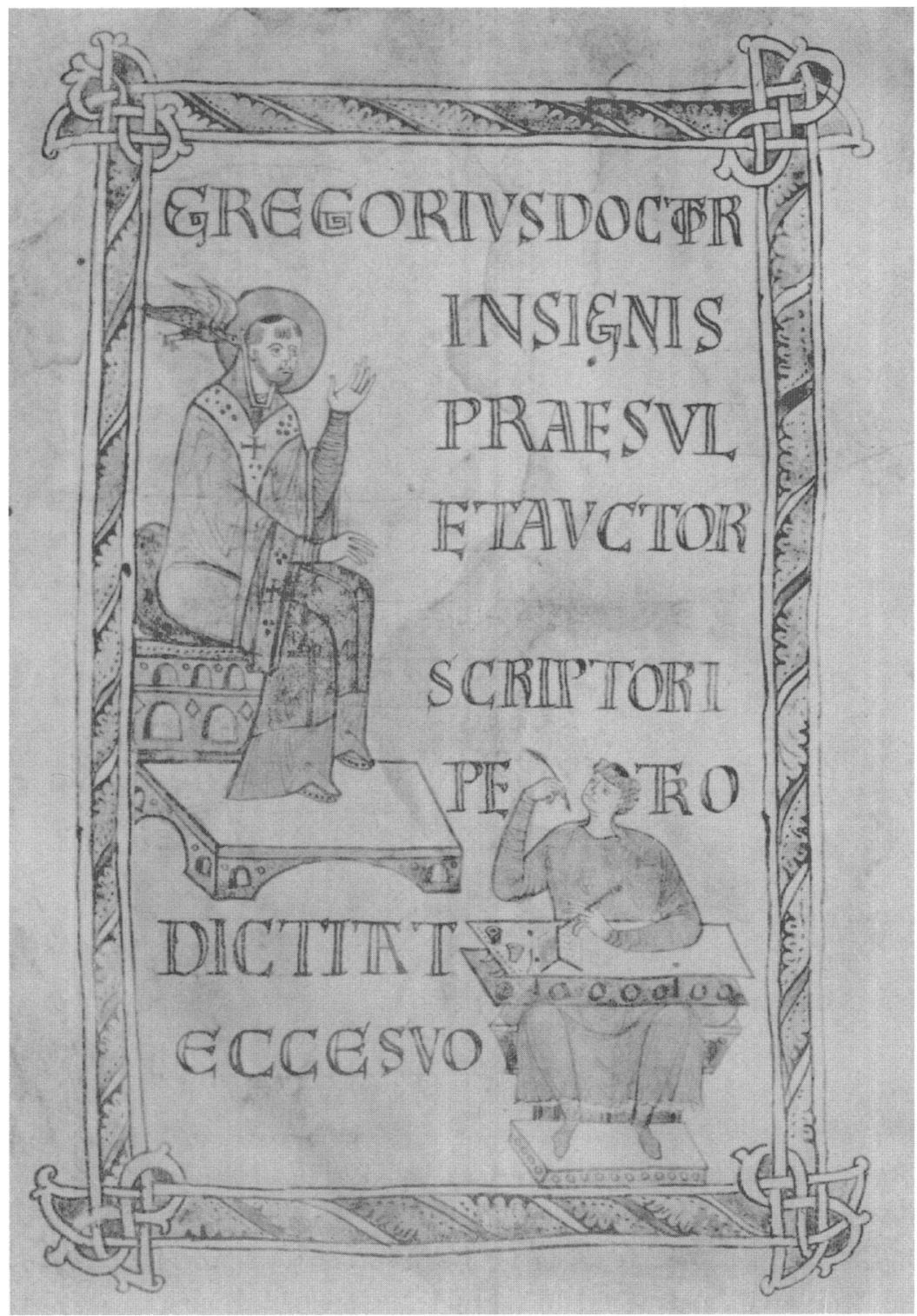

FIG. 8. Sacramentary of Warmundus, Ivrea, Bibl. Cap. cod. LXXXVI, fol. 8v, Pope Gregory I. (Reproduced courtesy of the Biblioteca Capitolare di Ivrea.)

to the prostration of the rulers at Christ's feet that Deshman described. But since they also offer precious volumes as gifts they are in a sense equivalent to Warmundus when he offers his books to the Virgin, begging her to reciprocate by giving him his dearest wish, entry to heaven. The hope of the rulers is that their offerings will tip the balance in favour of forgiveness, and qualify them too for life after death. In this context, by contrast, Warmundus can be understood best as representing his sacred office rather than his sinful humanity. He appears in this miniature as 


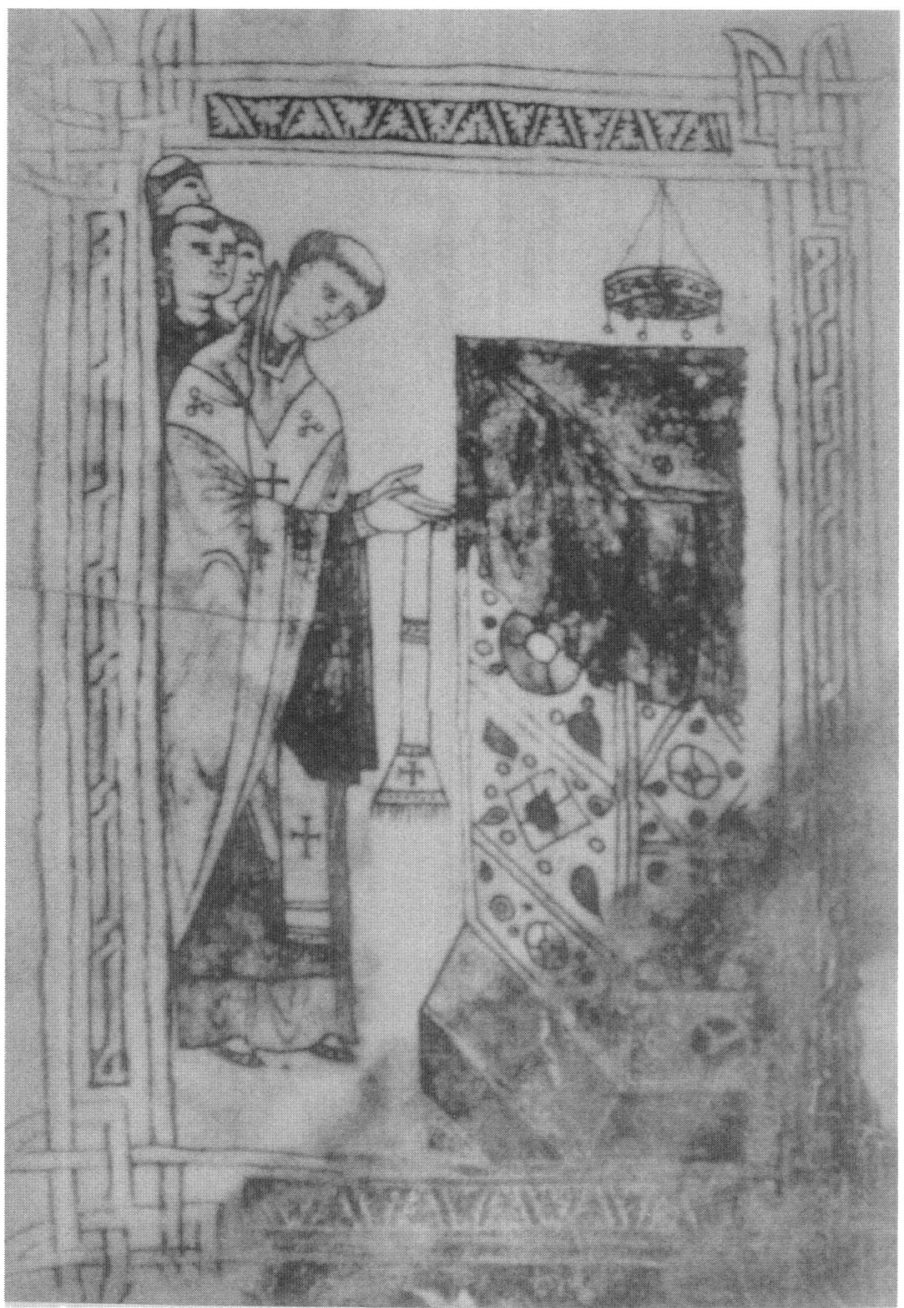

FIG. 9. Orationarium, Ivrea, Bibl. Cap. cod. IV (9), fol. 4v, Preparation for Mass. (Reproduced courtesy of the Biblioteca Capitolare di Ivrea.)

a witness, who by his gesture indicates Christ's wounds, and points to the message of salvation held by the blood of the crucified Christ. He no longer asks favours for himself, but humbly demonstrates the mystery that has come to pass in Christ's crucifixion.

\section{Warmundus's name in the Sacramentary's teXT: Dating the manuscript}

Warmundus's name, but without his portrait, occurs again in the frame of folio $160 \mathrm{v}$, usually entitled 'The Virgin Mary crowns Otto III' in the literature (FIG. 10). The distich reads, as if in Mary's words, 'I reward you with the gift of a crown, Caesar Otto, for your good defence of 


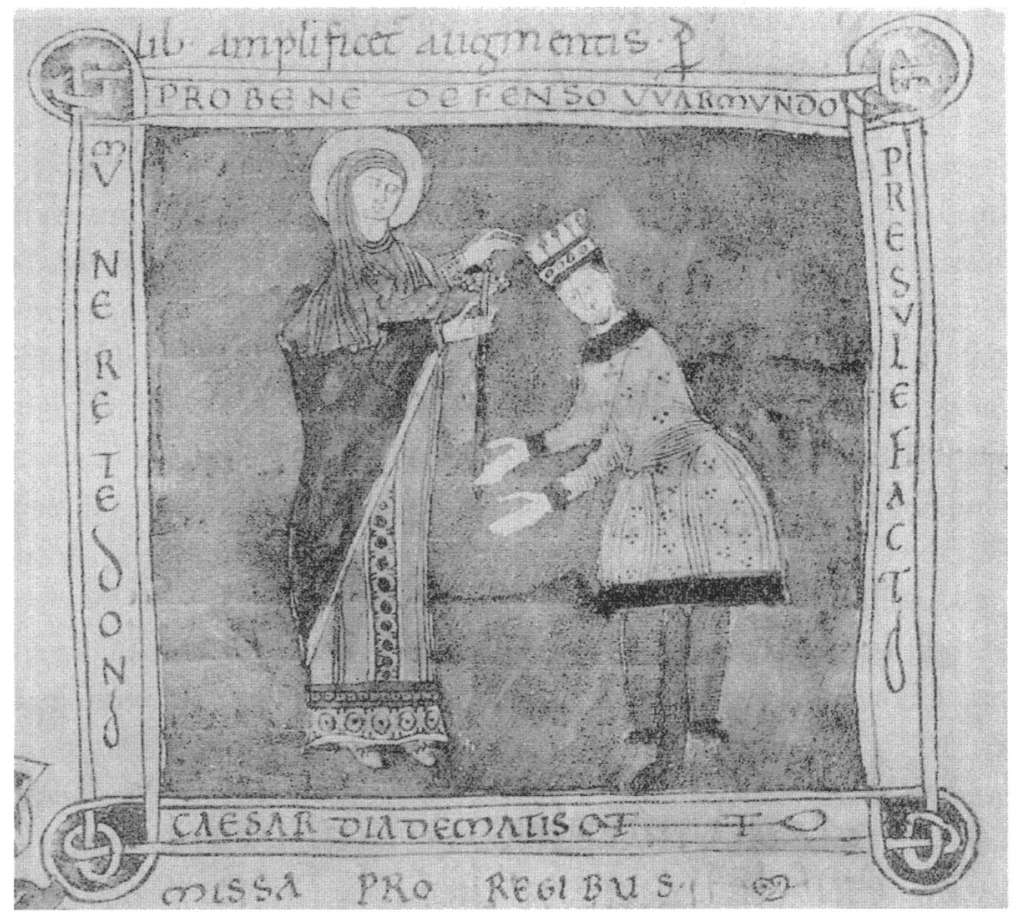

FIG. 10. Sacramentary of Warmundus, Ivrea, Bibl. Cap. cod. LXXXVI, fol. 160v, The Virgin Mary crowns Otto III. (Reproduced courtesy of the Biblioteca Capitolare di Ivrea.)

Warmundus, made prelate'..$^{37}$ The miniature shows the haloed Virgin, standing on the left, placing a crown on the head of a young, lightly-bearded monarch, who bends his head to receive it and puts out his hands to receive a sceptre from her. ${ }^{38}$ The special character of this miniature is underlined by the purple ground given to the painting, which illustrates the text of the Missa pro Regibus, the Mass of Kings, that follows. Most scholars have assumed from the diptych that the miniature commemorates the help that Otto III gave Warmundus in getting back Ivrea's diocesan lands from Arduin, as is recorded in a diploma dated 9 July 1000 (above, p. 220, n. 13), and that it constitutes a terminus post quem for the Sacramentary. ${ }^{39}$ The manuscript's dating also depends on the text of the Missa pro Regibus below the miniature, in which prayers are asked 'pro imperatori nostro Ottoni' ('for our Emperor Otto'). Plainly, the death of Otto III, last of the name, establishes a terminus ante quem for the manuscript. These two dates suggest an extremely narrow timeframe for the creation of the manuscript, between July 1000 and January 1002, probably

37 'PRO BENE DEFENSO WARMUNDO PRAESULE FACTO, MUNERE TE DONO CAESAR DIADEMATIS OTTO'. Translation based on that of Mayr-Harting, Ottonian Book Illumination (above, n. 20), II, 88.

38 See G.B. Ladner, L'immagine dell'imperatore Ottone III (Rome, 1988), 53.

39 Peroni, 'Il ruolo della committenza vescovile' (above, n. 5), 246. 
much too narrow for the work at hand, with its long text, 62 miniatures and abundant decorative initials and details.

There is, however, considerable evidence that the scene in folio $60 \mathrm{v}$ commemorates an earlier favour that Warmundus had received from an earlier emperor, Otto I, who had chosen him as bishop of Ivrea. Warmundus himself in his 'Sermo contra Arduinem', a tract that survives in the Ivrea Chapter Library's codex XX (10), folio 4v, recorded that he was bishop by the grant of the senior emperor, 'per senioris imperatoris concessionem'. This senior emperor, of course, was Otto I. Over the years the first Otto had provided protection of the faith for the many bishops he created, the so-called 'Ottonian Bishops'. A bishop's duty in return was to represent Otto and his interests in his region. In effect, Warmundus in folio $160 \mathrm{v}$ is asking the Virgin to bless the Emperor: the gesture by which she does this may relate to that on the Byzantine coins that had entered Ottonian lands in 972, along with the Byzantine princess, Theophanou, bride of Otto II. ${ }^{40}$

The choice of Otto I as the emperor portrayed in folio $160 \mathrm{v}$ was argued convincingly by Peroni and, more recently, by Mariaux. ${ }^{41}$ If one accepts their argument, it follows that the exact terminus post quem of 1000 for the Sacramentary is impossible, though the ante quem of Otto III's death in 1002 remains firm, since he was the last Otto of his line. Their theory has substantial advantages over the previous one, for it allows Warmundus time for his multifarious activities. The reconstruction of the east end of his cathedral, with its towers, hall-crypt and upper-storey ambulatory, will have taken a considerable time, and so will the production of books for the cathedral's own altars and for other patrons. ${ }^{42}$ So, even if the miniature were produced in the seven years before the death of Otto I in 973, which seems unlikely, the prayers for an emperor Otto in the Missa pro Regibus could refer equally to any one of the three Ottos.

\section{WARMUNDUS AS WRITER AND POET}

Warmundus's name does occur again, once more without a likeness, in the cluster of illustrations at the very end of the book, where each of the last four folios is divided four ways by text. ${ }^{43}$ The symbols of the evangelists are shown on folio 221 , and the twelve apostles, four each on folios $22 \mathrm{lv}, 222$ (FIG. 11) and 222v. The poems are written in a simple variant of a form known as carmina figurata, which was invented in the fourth century by the poet Publilius Optatianus Porphyry, and had been popular since Carolingian times. ${ }^{4+}$ The folios establish Warmundus's authorship of the poems that occur throughout the manuscript. Each folio displays a simple

40 See Mariaux, Warmond d'Ivrée (above, n. 1), 88-93.

41 Peroni, 'Il ruolo della committenza vescovile' (above, n. 5), 247-8; P.-A. Mariaux, 'Lillustration de la Missa pro Regibus, sur les pas d'OHon', Images, 84-93.

42 More than 50 survive, noted by A. Cohen, 'Review of P.-A. Mariaux, Warmond d'lvrée et ses images', Speculum 79 (2004), 795-8, esp. p. 797.

43 Peroni, 'Il ruolo della committenza vescovile' (above, n. 5), 256-7, fig. 19; Magnani, Le miniature del sacramentario d'lvrea (above, n. 15), 39-40.

44 Porphyry's late ninth-century codex in Ivrea (Bibl. Cap. cod. LXX (24)) may have been the direct source of inspiration for the miniatures on folios 221 and 222. See Mariaux, Warmond d'Ivrée (above, n. 1), 256. 
grid within which letters combine at the intersections. The letters of the central pathways always form the name Warmundus, and each quarter-page illustrates and frames a holy being or symbol from the poem's text. ${ }^{45}$ Whereas the Carolingian poems might be used to glorify the Cross 'through Christ's victory in the crucifixion', ${ }^{46}$ and the cross-shaped divider became the site of the interlocking words Jesus and Christus, ${ }^{47}$ each crossway of Warmundus's four-folio poem bears his own name intersecting at the central letter M. Each repetition forms the heart of a prayer to Christ that runs repetitively around the frame and into the cross itself. 'WARMUNDUM VATEM SUPERO, REX, ERIGE NUTU' ('King, lift up the poet Warmundus above the brute beasts') appears on the Evangelist symbols page, and three more single lines of poetry ornament the three Apostle pages: 'EXCOLE WARMUNDI MORES, FONS, PRESULIS, ALME' ('Benevolent Spring, embellish the character of Prelate Warmundus'), on folio 22lv; 'MUNDI FORMATOR WARMUNDUM PROTEGE VATEM' ('Creator of the World, protect the poet, Warmundus') on folio 222 (FIG. 11); and 'RERUM, PONTIFICEM WARMUNDUM DIRIGE, RECTOR' ('Rector of everything, guide the pontiff, Warmundus'), on folio 222v. ${ }^{48}$ Two of these four folios name Warmundus as 'poet': folios $22 \mathrm{l}$ and 222. These lines confirm him as author of the poems, rather than the patron of another poet. ${ }^{40} \mathrm{In}$ addition, some of the poems in the main body of the text proclaim his authorship in as many words, among them folio $1 \mathrm{lv}$ (FIG. I) and folio 160v (FIG. 10), as we have seen.

To summarize, there is ample evidence of Warmundus's role both as patron of the Sacramentary and as author of the poems that comment on its miniatures and adom the frames of each of them. His 'portraits' framed by square halos also have come down to us twice over, and depict him as a middle-aged cleric with a tonsure and a distinctive pattern to his straight dark hair. But in addition to our knowledge of his features and of his direct involvement in the volume, evidence can be gleaned there about his concerns in the period of its construction, which probably occurred during the last quarter of his life. Mariaux has argued that the main series of miniatures, which includes both the Blessing of the Chrism and the Crucifixion, each with Warmundus's 'portrait', was carried out by a master artist from Milan, who worked at Ivrea between 980 and $996 .^{50}$ The bishop's age at the time the books were under way can be estimated roughly, using as the baseline the 30 years that ordinarily would have been required of him in the late $960 \mathrm{~s}$ before consecration as

45 Magnani, Le miniature del sacramentario d'Ivrea (above, n. 15), 39.

46 C. Chazelle, The Crucified God in the Carolingian Era, Theology and Art of Christ's Passion (Cambridge, 2001), chapters 2 and 3, esp. pp. 14-15.

47 Chazelle, The Crucified God in the Carolingian Era (above, n. 46), 107, fig. 14, for Hrabanus Maurus's poem 23, In honorem sanctae crucis, Biblioteca Vaticana, Lat. cod. Reg. lat. 124, fol. 30v.

48 G.B. Ladner, 'Die Italienische Malerei im XI Jahrhundert', Jahrbuch der Kunsthistorischen Sammlungen in Wien 5 (1931), 33-160, esp. pp. 130-60, 'Das Sakramentar des Bischofs Warmundus von Ivrea, cod. 86 der Bibliothek des Domkapitels in Ivrea', figs 157-60 for fols 221-222v, and n. 249.

49 Mariaux discovered on codicological grounds that these folios did not form part of the original programme of the codex, but, along with a section at the start of the volume, were added very soon after its completion. Mariaux, Warmond d'Ivreée (above, n. 1), 69-76.

50 See Mariaux, Warmond d'lvrée (above, n. 1), 'Hypothèse sur la datation du sacramentaire de Warmond', 24l-8, esp. p. 248. Mariaux's date depends on the identification of the main scribe, 'C', by several 


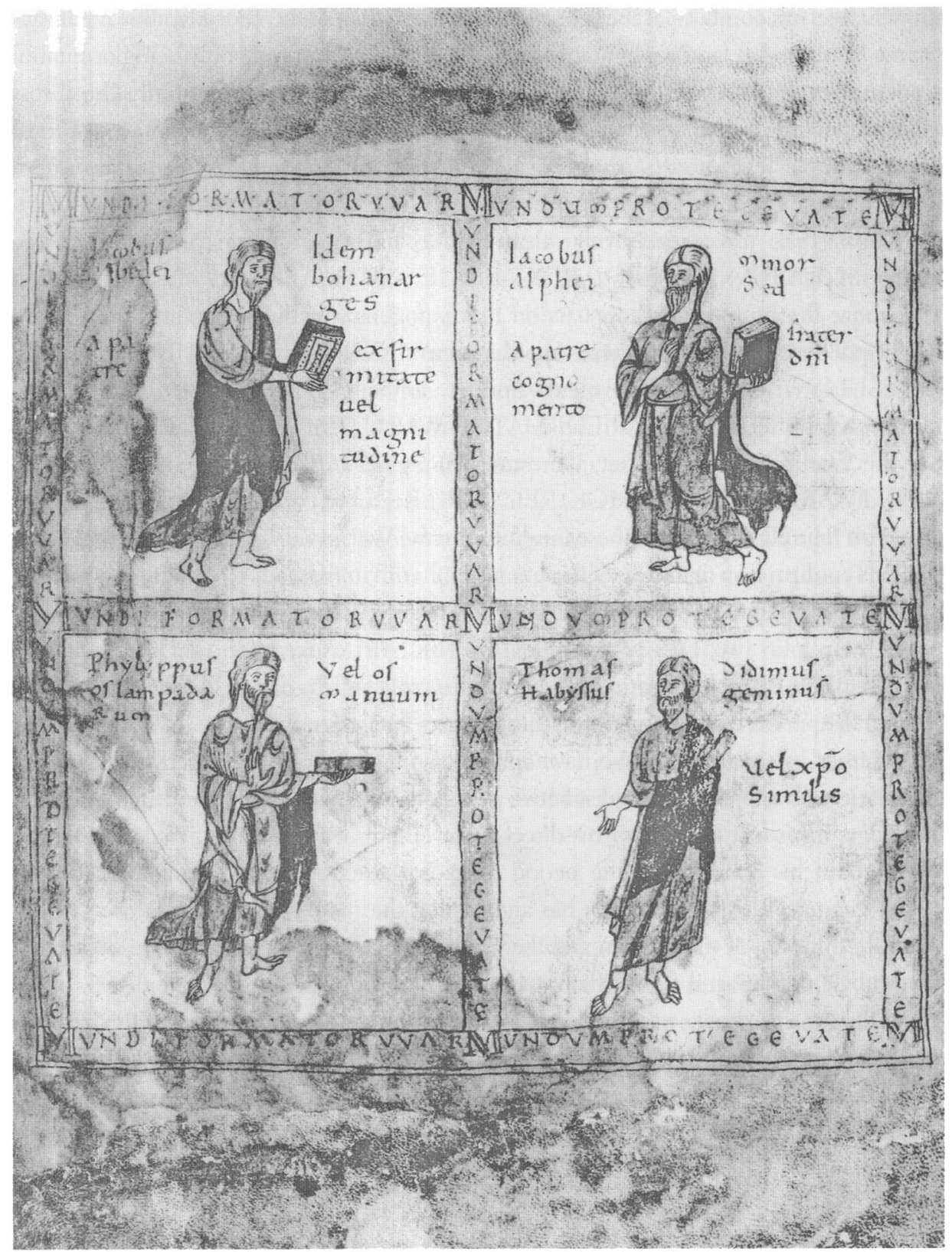

FIG. 11. Sacramentary of Warmundus, Ivrea, Bibl. Cap. cod. LXXXVI, fol. 222, Apostles, with Warmundus's poem. (Reproduced courtesy of the Biblioteca Capitolare di Ivrea.)

scholars (Luigi Magnani, Derek Turner and Beat Brenk) as the Milanese miniaturist who illustrated Arnulph II's prayer-book (London, British Museum, Egerton 3763) around the year 988. See also B. Brenk, 'La committenza di Ariberto d'Intimiano', in Il millennio ambrosiano II: la città del vescovo dai Carolingi al Barbarossa (Milan, 1988), $124-55$, esp. p. 149. 
bishop. ${ }^{51}$ By 980 he would certainly have been over 40 , and by 996,56 or more years old, with four years to go before the millennium. ${ }^{52}$ Since it is unlikely that he was a young man at the time he commissioned Ivrea's illustrated liturgical manuscripts, they should reveal his interests and priorities as he approached old age. The text of the liturgy itself as contained in the Sacramentary had been largely formalized on the Gregorian model in the late ninth century, a 'time of energetic creation and synthesis in ritual life. ${ }^{53}$ The choice of which episodes from the numerous possibilities in scripture, liturgy and tradition should receive a whole- or half-page illustration would have been the bishop's, probably with input from the cathedral's clergy and the miniaturist. A core of subjects would always take priority - the major feasts of the Church and its most famous saints and martyrs, among them Peter and Paul, Lawrence, Stephen and John the Evangelist. All were included in this category at Ivrea. These martyrdoms were also illustrated in the contemporary sacramentaries made at Fulda: one for Udine (Bibl. Cap. cod. 1), from the late tenth century, and Göttingen's Universitätsbibliothek cod. theol. 231, dating around 975.

The Warmundus Sacramentary, though, goes much further than the basics it shares with the Fulda layout, for it includes two important sets of illustrations that are without precedent in surviving liturgical manuscripts. Both deal with aspects of death: one illustrates the order of Christian burial, and the other, the tortures inflicted on the martyrs who are commemorated on All Saints' Day, 1 November. These two sets of miniatures, mentioned only briefly by Mariaux, deserve closer study as a group, for Warmundus's choices reveal his serious interest not only in the cult of martyrs, but in death itself. ${ }^{54}$

\section{IMAgES OF DEATH in THE Warmundus SaCramentary}

\section{The order of Christian burial}

This is especially well shown in his remarkable extended cycle of ten illustrations for the Ordo in Agenda Mortuorum, the liturgy for the dying and the dead. ${ }^{55}$ There, the artist illustrated each

51 In the late eighth century, the minimum age for ordination to the subdiaconate was 21 years, to the diaconate, 24 years, and to the priesthood, 30 years. See Hrabanus Maurus, Abbot of Fulda (776 or 784-856), De Institutione Clericonum I, 13; Migne, PL 107, col. 306A. These rules were close to Warmundus both in time and in geographical location. Less relevantly, perhaps, in the mid-seventh century, Canon 19 of the Fourth Council of Saragossa (633) had declared that 'a bishop should not be consecrated before the age of 30': J.D. Mansi, Sacrorum Conciliorum Nova et Amplissima Collectio X (Florence/Nenice, 1758-98); reprinted (Graz, 1960, vol. 9), 625. There may well have been exceptions to these rules.

52 For evidence on Warmundus's age, see $\mathbf{n} .2$.

53 F. Paxton, Christianizing Death (Ithaca, 1990), 207.

54 Mariaux, Warmond d'Ivrée (above, n. 1), 108, for fols $110 \mathrm{v}, 111$ and $111 \mathrm{v}$ of the Sacramentary, and for fol. 41 of the Benedictional (Ivrea, Bibl. Cap. cod. XVIII (8)).

55 See J.-C. Schmitt, La raison des gestes dans l'occident médieval (Paris, 1990), 207-24, and P. Geary, Phantoms of Remembrance. Memory and Oblivion at the End of the First Millennium (Princeton, 1994), 53-9, and plates $1-10$, for illustration and discussion of these ten images. 
stage of a Christian's mortal sickness and death, matching each illustration with the appropriate liturgical prayer from the church's cycle for the 'setting forth of the soul'. Thus we see the mortal illness, and the imposition of a penance in preparation for the viaticum, the last communion. Preparation for impending death continues, with readings, chants and prayers from the clergy, and always the grieving wife and family. The patient expires, as indicated by the small homunculus that issues from his mouth and represents the soul. Funerary care follows: the washing and wrapping of the body, and its placement on the bier, which then leaves the house in cortège for the church, site of a prayer service. Mass is celebrated and the cortège proceeds from the church to the burial place, where a sarcophagus is opened by the sextons and the body is placed within. ${ }^{56}$ Damien Sicard, in his La liturgie de la mort, provided the prayers and readings that accompanied each stage of this last journey to the grave. ${ }^{57}$ These are precisely illustrated by the drawings in the Warmundus Sacramentary, which appear to be the lively and original products of close observation of daily life. They contrast in this respect with the only other extant example of such a cycle, the abbreviated series of three episodes in the Göttingen Sacramentary, done in a conventional style. ${ }^{58}$

\section{The All Saints' Day illustrations and their possible sources}

Turning to the other unprecedented set of illustrations, depicting the sufferings of the martyrs for All Saints' Day, Warmundus devoted a total of three full-folio miniatures to the subject of their torture (FIGS 12-14). The nude or semi-nude figures of the martyrs contrast with the clothed and shod figures of their tormentors, who outnumber their victims in a ratio of eleven to eight. This nakedness may well be associated with the needs of the specific torture being applied, but it also has the effect of enhancing the martyrs' humiliation, which added to his or her suffering and hence to the emotional impact on the viewer. ${ }^{59}$ The viewer of these miniatures, of course, will have been Warmundus, and his successors at the Cathedral's high altar.

\section{Possible sources in the manuscript art of the period}

First, let us consider the relationship between these torture scenes and other contemporary illustrations for All Saints' Day. This relatively late feast was introduced to the calendar when

56 These images were the subject of a class project in my course 'Death in the Middle Ages' at the University of Victoria in 1997. Discussions and written papers contributed significantly to my understanding of this series. I thank all my students for their interest and ideas.

57 See D. Sicard, La liturgie de la mort dans l'église latine dès origines à la réforme carolingienne (Münster, 1978), with a summary on p. 30.

58 For the Göttingen Sacramentary, the Agenda Mortuorum episodes are illustrated in E. Palazzo, Les sacramentaires de Fulda. Étude sur l'iconographie et la liturgie à l'époque ottonienne (Liturgiewissenschaftliche Quellen und Forschungen 77) (Münster, 1994), esp. figs 52 (fol. 185; Visiting the Sick), 53 (fol. 187; Confession (?)) and 54 (fol. 192v; Extreme Unction). The latter is also illustrated in Mayr-Harting, Ottonian Book Illumination (above, n. 20), II, 129, fig. 80.

59 I thank Michael Bury for this suggestion. 


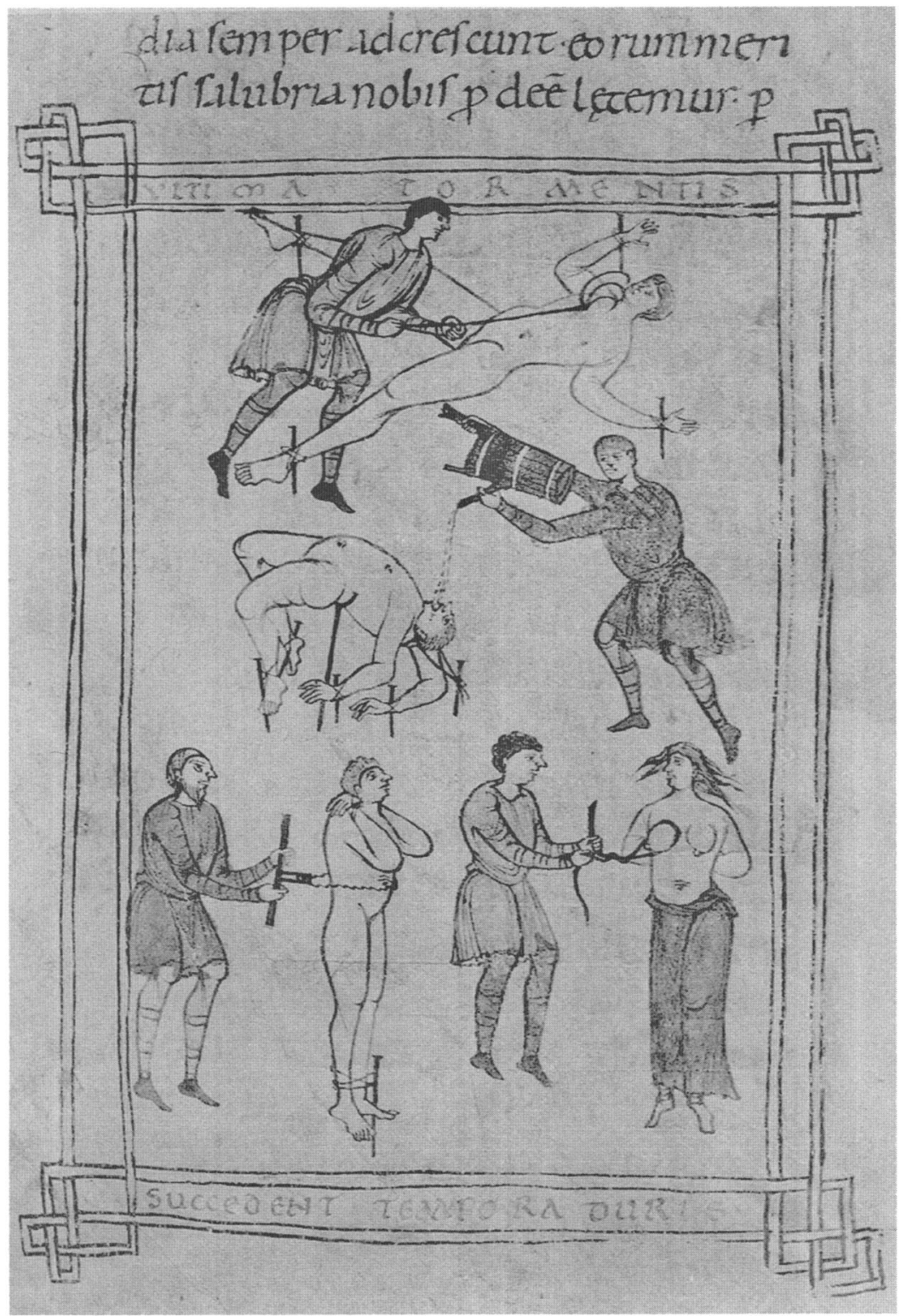

FIG. 12. Sacramentary of Warmundus, Ivrea, Bibl. Cap. cod. LXXXVI, fol. 110v, Suffering martyrs, illustrating All Saints' Day. (Reproduced courtesy of the Biblioteca Capitolare di Ivrea.)

Pope Boniface IV dedicated the Pantheon in Rome to Santa Maria ad Martyres in 609 or $610 .^{60}$ The building had been thought to be the home of evil spirits from the pre-Christian past, when it

60 Boniface IV (608-15); L. Duchesne (ed.), Liber Pontificalis, 3 vols (Paris, 1886-92), translated in R. Davis, The Book of Pontiffs (Liber Pontificalis) (Liverpool, 1989), 62-3. 


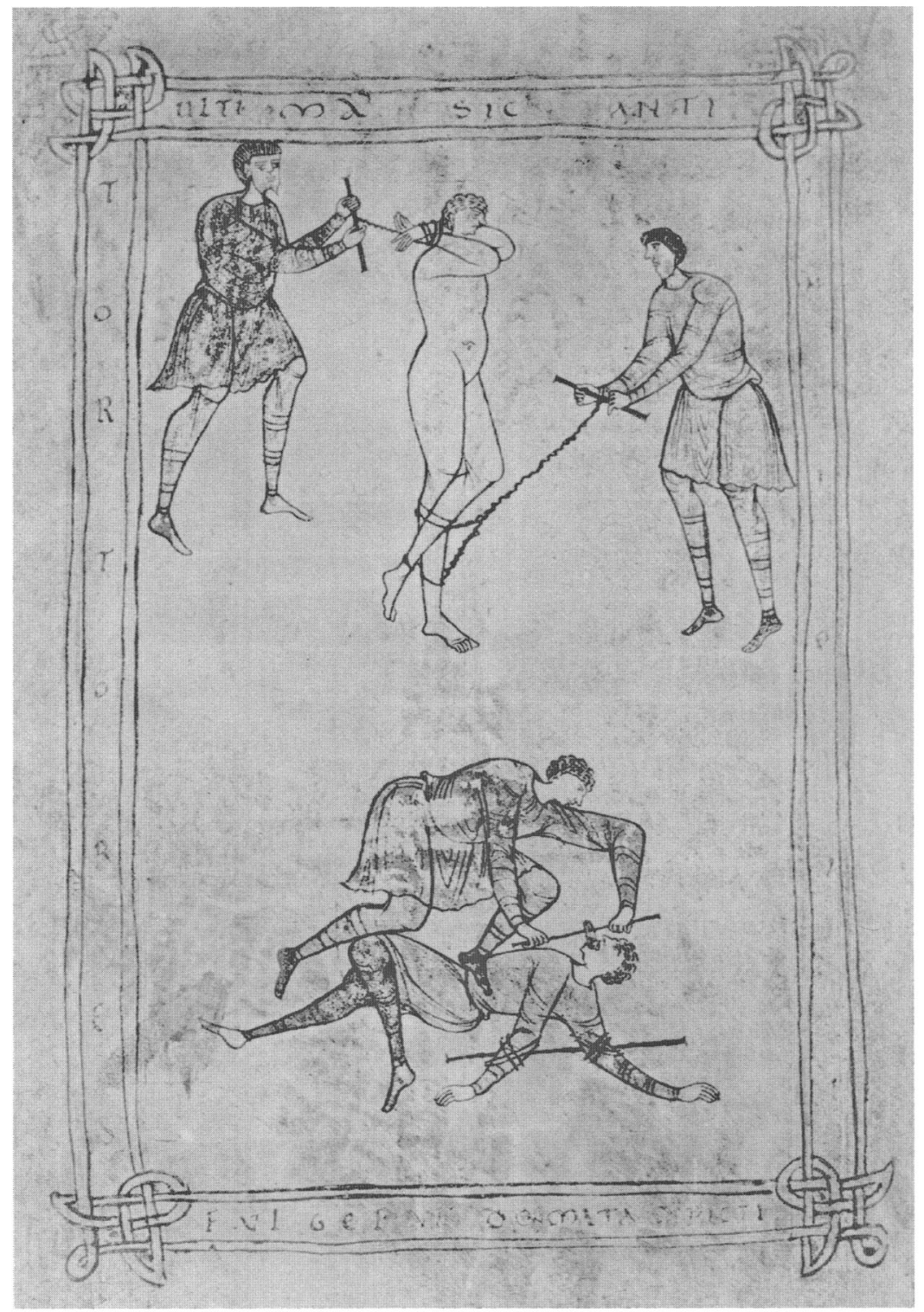

FIG. 13. Sacramentary of Warmundus, Ivrea, Bibl. Cap. cod. LXXXVI, fol. 111, Suffering martyrs, illustrating All Saints' Day. (Reproduced courtesy of the Biblioteca Capitolare di Ivrea.)

had been dedicated to all the pagan gods, as the name 'Pantheon' suggests. Its dedication as a church nullified its pagan past, and the bones of innumerable Christians were brought in from the catacombs to sanctify it. At first All Saints' Day was celebrated on 13 May, the date of the Pantheon's conversion to a church, and this is the date of record in the Warmundus 


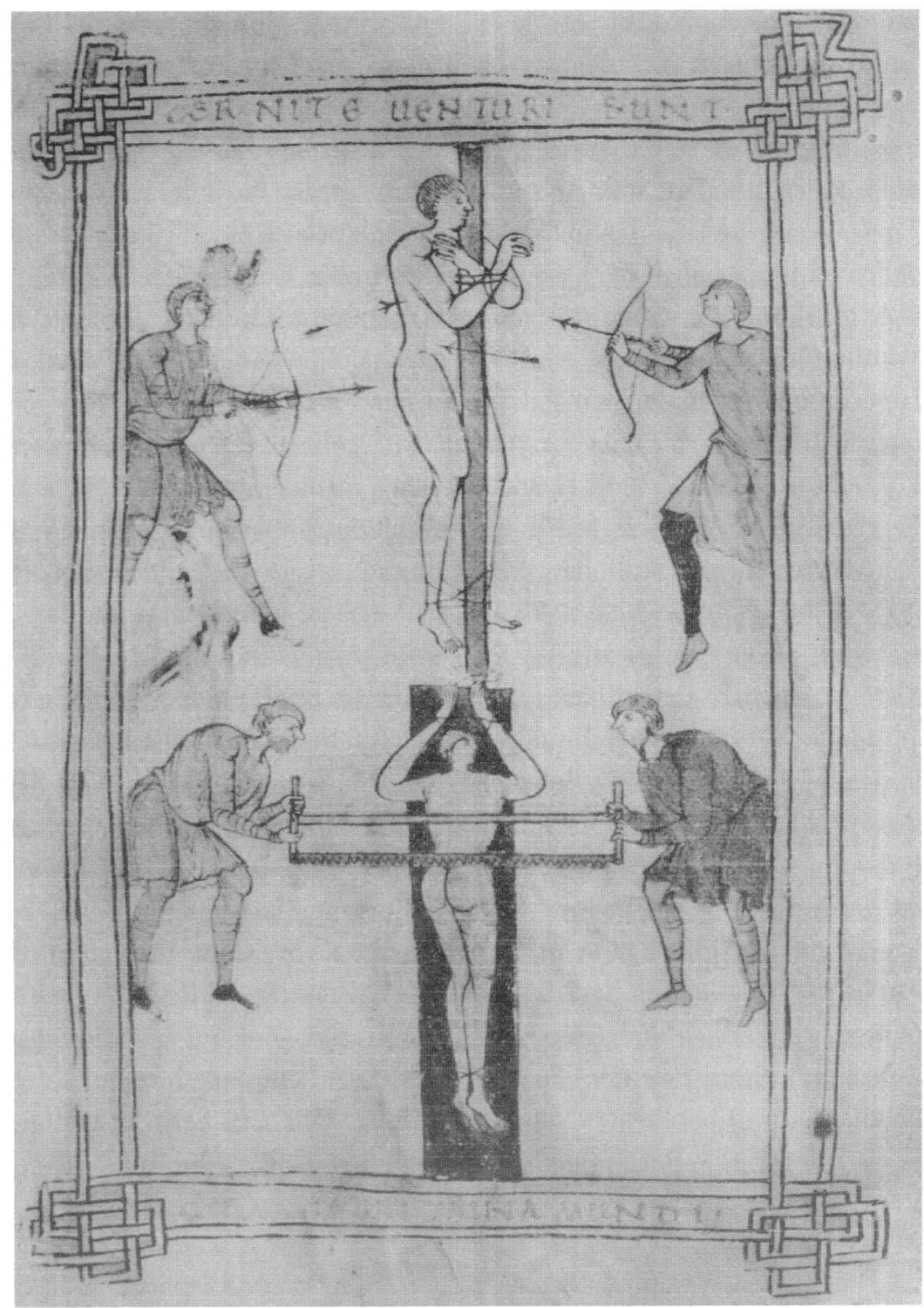

FIG. 14. Sacramentary of Warmundus, Ivrea, Bibl. Cap. cod. LXXXVI, fol. $111 \mathrm{v}$, Suffering martyrs, illustrating All Saints' Day. (Reproduced courtesy of the Biblioteca Capitolare di Ivrea.)

Sacramentary. ${ }^{61}$ But in the eighth century Pope Gregory IV moved the feast to 1 November, and extended the annual celebration to the whole world. It had special significance at Fulda, where the abbey's great church was consecrated on 1 November 819 and reconsecrated after the great

61 See Magnani, Le miniature del sacramentario d'lvrea (above, n. 15), 13-15, esp. p. 14, for a summary of the text, and Sacramentario for the 13 May date on folio 77v, facing the Ascension on folio 78r: 'III IDUS MAII NATALE SANCTE MARIAE AD MARTYRES'. 
fire of 937 on All Saints' Day, $948 .^{62}$ Fulda's original dedication and its reconsecration to All Saints suggest that it could have been there, more than anywhere else, that a formula might have developed to celebrate the martyrs' sufferings on the abbey's patrimonial feast. But far from dwelling on the martyrs' torments, Fulda chose to celebrate their triumph by showing them seated in serried ranks in heaven, as described in the fifth chapter of the Book of Revelation. They are singing Hosanna to the Mystic Lamb, whose blood given in sacrifice spurts out, and is collected in a chalice by a woman who signifies Ecclesia, the Church. Both the Göttingen (fol. 11lr) and the Udine (fol. 66v) sacramentaries illustrate All Saints' Day in this way. The Warmundus Sacramentary, however, which follows Fulda in so many respects, such as the large number of major saints' days illustrated and the focus on their individual martyrdoms, rejects the Fulda formula for the martyrs' collective feast. Peroni compared the full-page illustrations of folios $110 \mathrm{v}, 111$ and $111 \mathrm{v}$ to 'a manual of torture'. ${ }^{63}$ No precedents have survived in early manuscript art for these illustrations. Individually, though, the All Saints' Day martyrdoms at Ivrea could have been inspired by early medieval passionals, or by the illustrated lives of the martyrs, which were a special area of interest from the late tenth century at the scriptoria of both Fulda and Reichenau, just across the Alps from Ivrea. ${ }^{64} \mathrm{~A}$ few examples of these do survive, though none has a direct connection to Ivrea. The earliest, dating from around the year 900, is an illustrated version of the passion of Romanus of Antioch, as described in poem 10 of Prudentius's Peristephanon Liber, Crowns of Martyrdom. This manuscript (Bern, Burgerbibliothek cod. 264), which was probably made at Reichenau, is devoted to the works of Prudentius, and contains the texts of ten of the fifteen poems of his Peristephanon, of which only the passions of Cassian, in poem 9, and of Romanus, in 10, are illustrated. ${ }^{65}$ Two other illustrated lives of the martyrs date from around 970. The Life of Saints Kilian of Würzburg and Margaret of Antioch (Niedersächsische Landsbibliothek, Hannover, MS I.189), recounts the life of two martyrs, a bishop, Kilian, and a virgin, Margaret, and was probably made and illustrated at Fulda for private devotions in a nunnery. ${ }^{66}$ An illustrated version of the passion of Saint Agatha (Paris, Bibliothèque Nationale, MS lat. 5594) has been located to Burgundy and dated

62 Original dedication, Hrabanus Maurus, 'Poem on the Dedication', Monumenta Germaniae Historica, Poetae Latini II (Hanover, 1878), ii, 205. For the rededication, see Mayr-Harting, Ottonian Book Illumination (above, n. 20), II, 15l-3.

63 Peroni, 'Il ruolo della committenza vescovile' (above, n. 5), 254, 'Le serie per la festa di Ognisanti è una descrizione di supplizi puntuale nella varietà come un prontuario'.

64 Magnani, Le miniature del sacramentario d'Ivrea (above, n. 15), 160.

65 See C. Hahn, Portrayed on the Heart, Narrative Effect in Pictorial Lives of Saints from the Tenth through the Thirteenth Century (Berkeley/London, 2001), 61-2; and C. Hahn, 'Speaking without tongues: the Martyr Romanus and Augustine's theory of language in illustrations of Bern Bibliothek codex 264', in R. Blumenfeld-Kosinski and T. Szell (eds), Images of Sainthood in Medieval Europe (Ithaca, 1991), 161-80. Also Hahn, Portrayed on the Heart (above), 342, for the specifications and contents of the Bern manuscript.

66 C. Hahn, Passio Kiliani, Ps. Theotimus, Passio Margaretae, Orationes. Faksimile-Ausgabe des Codex Ms 1.189, aus dem Besitz der Niedersächsische Landesbibliothek, Hannover. Kommentarband (Codices selecti 83) (Graz, 1989). See also Hahn, Portrayed on the Heart (above, n. 65), 22-3. 
to the late tenth or early eleventh century by Magdalena Carrasco. ${ }^{67}$ Carrasco suggested that textual sources, both legendaries, collections of martyr stories and libelli (booklets with a single saint's story), probably existed as far back as the Carolingian period or even in early Christian times. They may well have contained important source material for Warmundus's individual images of saints under torture. ${ }^{68}$ Nevertheless, no illustrations of torture in the abstract - that is, outside the context of a specific saint's life - survive into the manuscript art of the tenth and eleventh centuries. The earliest survivor in that genre, the Stuttgart Passionary, from the start of the twelfth century, encloses the torture scenes within the initials. ${ }^{69}$ They do not starkly occupy the whole-page ground, as in the Warmundus Sacramentary.

\section{Possible sources in monumental art}

A second possible source for the All Saints' Day miniatures is monumental art. Here, too, the ravages of time have taken their toll. Although wall-paintings illustrated the passions and deaths of non-biblical saints with graphic realism from the seventh and eighth centuries on, it is rare that they survive in anything but fragmentary condition. ${ }^{70}$ A prime example in the east, and at the top level of patronage, is known only from a rhetorical description. Ignatius the Deacon described the paintings that the patriarch Tarasius (ob. 806) had commissioned for a monastic church on his patrimonial estate beside the Bosphorus at Stenon. The church, appropriately dedicated to All Saints, depicted more than a dozen forms of martyrdom in detail: none of the martyrs were named. ${ }^{71}$ In central Italy, the mid-eighth-century Theodotus Chapel at Santa Maria Antiqua in Rome, protected by a landslide for over a thousand years, illustrates the sufferings and death of a child saint, Quiricus, and his mother, Julitta, in a wellpreserved cycle of paintings. ${ }^{72}$ By contrast, only faded fragments of early ninth-century wall-paintings of martyrdoms survive in the transept of nearby Santa Prassede. Caroline Goodson, using early twentieth-century photographs, has identified the martyrs by name as being among the saints whose remains were transferred to the church by Paschal I in $817 .^{73}$ Nothing comparable survives in Warmundus's immediate area, but the paintings of the Apocalypse at the baptistery of Novara, dated to immediately before the year 1000 , as well as

67 M.E. Carrasco, 'An early illustrated manuscript of St. Agatha (Paris, Bibl. Nat., MS lat. 5594)', Gesta 24 (1985), 19-32, esp. p. 25 and fig. 12, where torturers remove both Agatha's breasts with pincers. This suggests a different version of the life from that followed by Warmundus's scribe.

68 For legendaries, see G. Philippart, Les légendiers latins (Turnhout, 1977). Philippart also discussed libelli briefly, on p. 99 .

69 A. Boeckler, Das Stuttgarter Passionale (Augsburg, 1923), 7.

70 L. Jessop, 'Pictorial cycles of non-biblical saints: the seventh- and eighth-century mural cycles in Rome and contexts for their use', Papers of the British School at Rome 67 (1999), 233-79, esp. pp. 233-5.

71 S. Efthymiadis (trans. and ed.), The Life of the Patriarch Tarasios by Ignatios the Deacon. Greek Text with Translation and Commentary (Aldershot, 1998), 194-6.

72 See, most recently, Jessop, 'Pictorial cycles of non-biblical saints' (above, n. 70), 236-55.

73 See C. Goodson, 'The relic translations of Paschal I (817-24): transforming city and cult', in A. Hopkins and M. Wyke (eds), Roman Bodies: Antiquity to the Eighteenth Century (London, 2005), 123-41. 
the early eleventh-century paintings at Sant'Orso in Aosta, prove that powerful wall-paintings were being produced in Piemonte in Warmundus's time. ${ }^{74}$

\section{Written sources: manuscripts without illustrations}

Although we have seen that very few illustrated manuscripts of saints' lives and deaths survive from the central Middle Ages, lives and martyrologies without illustrations are much more numerous. At Ivrea, they include a tenth-century Vitae Sanctorum or Passionary (Ivrea, Bibl. Cap. cod. LXXI (25)) and the ninth-century Martyrology of Adon (Ivrea, Bibl. Cap. cod. XXXVIII (20)), which may have been the official martyr text of the cathedral. ${ }^{75}$ The Vitae Sanctorum is in an extreme state of disintegration, but was studied by Albert Poncelet. ${ }^{76}$ Although many leaves were fused together, and others had deteriorated into dust, he was able to make a partial reading of the manuscript. It consists of part of a liturgical calendar, where the saints' days tell of the details of their martyrdoms, and record the dates of their births into heaven. Two martyrs died in April, eleven in May, and five in June. A further seven died between July and November. ${ }^{77}$ Most of them faced decapitation by the sword, others death by fire. The Chapter Library's Martyrology of Adon expounds the passions and deaths of most of the martyrs listed under their feast-days in graphic detail. It is rich in details of the sufferings they endured, and the ways in which they were done to death. These daily recitations of anguish and death must have made a deep impression on those who heard them, and perhaps especially on the clergy, who had listened to them daily at the chapter assembly, and read them aloud at prime to those who were present. ${ }^{78} \mathrm{I}$ believe that these reiterated texts were another major factor in Warmundus's preoccupation with death, its depiction and its celebration. As Felice Lifshitz

74 For the Novara baptistery, see J. Wettstein, La fresque romane; études comparatives (Bibliothèque de la Société Française d'Archéologie 2, 9) (Geneva, 1971); M.B. Mauck, The Apocalypse Frescoes of the Baptistery in Novara, Italy (Ph.D. thesis, Tulane University, 1975).

75 S. Gavinelli, 'Alle origini della Biblioteca Capitolare', in Cracco (ed.), Chiesa di Ivrea (above, n. 4), 535-66, esp. p. 537. The two codices are listed in M. Ferrari and S. Gavinelli 'Elenco dei codici', 975-88 in the same volume, at pp. 981, 983.

76 A. Poncelet, 'Catalogus Codicum Hagiographicorum Latinorum Bibliothecae Capituli Eporediensis', Analecta Bollandiana 41 (1923), 326-56, esp. pp. 335-56.

77 In April, Saints George (23rd) and Mark (25th); in May, Invention of the Cross (3rd); Alexander, Eventus and Theodolus (3rd); Gordianus and Epimachus (10th); Nereus and Achilleus (12th); also Pancratius (12th); Pastor, Pontianus and Timothy (19th); in June, Primus and Felicianus (9th); Vitus (15th); Gervasius and Protasius (19th); in July, Nazarius and Celsus (28th). The calendar, with large gaps caused by missing pages, then passes to September, with Adrian (8th), Eufemia (16th), Michael (29th); and then Bavon (1 October) and Anianus (17 November). Saints' day dates are those listed in either J. Dubois and G. Renaud (eds), Le Martyrologie d'Adon (Paris, 1984), or in The Roman Martyrology (trans. R. Collins) (Westminster, 1946), or both.

78 This ceremony was enforced by the Capitula Proprie ad Episcopos, issued at the church councils held at Aachen in 816 and 817 by Louis the Pious. This covered the duties of bishops throughout Francia from the year 817 on, and required the reading of the martyr lists daily in the churches and monasteries of Louis's realms. See T. Head, 'Postscript: the ambiguous bishop', in J.S. Ott and A. Trumbore Jones (eds), The Bishop Reformed. Studies of Episcopal Power and Culture in the Central Middle Ages (Aldershot, 2007), 250-63, esp. pp. 254-5. 
has said, 'it required a long and winding road ... to establish as Christian orthodoxy the view that one could achieve perfection through dying ... and that one should venerate those who had done so' ${ }^{79}$ But by Warmundus's day this orthodoxy had been accomplished, and is illustrated in his manuscripts, showing that he accepted this attitude to death as his Christian duty.

Warmundus's All Saints' Day miniatures are remarkable for omitting both the martyrs' names and their actual death-throes. Another of Ivrea's manuscripts, the Benedictional (Ivrea, Bibl. Cap. cod. XVIII (8)) also adheres to the convention of anonymity, but not of death itself. It features a remarkable image of death by the sword on folio 41 , where it is unframed and situated in the heart of the text of the bishop's blessing for All Saints' Day. An executioner is shown in action, a severed head at his feet, and a drawn sword and its scabbard in his two hands. He runs toward six more young men, who wait in line for death. A richly-dressed woman kneels at the feet of a second executioner, who is drawing his sword (FIG. 15). This anonymous scene contains many clues to allow it to be identified as the martyrdom of Felicitas, a Roman widow, and her seven sons. ${ }^{80}$ Here, too, All Saints' Day was to be marked by an epic martyrdom, its anonymity ensuring its universality, though here it is death itself, not torture, that is celebrated.

In marked contrast to both the Benedictional's folio 41 and the three All Saints' Day pages, the major saints, such as Peter and Paul, Stephen, Andrew and John the Evangelist, who are chosen for illustration in the Warmundus Sacramentary are all named. In addition, the means of death is illustrated for each feast-day, the saint's day of entry into heaven, while his name and verses appropriate to his story are recorded in the miniature's painted frame. These details, too, contrast with the three All Saints' Day folios, which are concerned primarily with suffering as a stage on the way to heaven. The martyrs' endurance and their faith allows them to demonstrate the freeing of the spirit from the body while they yet live, so that the soul is ready to ascend when death inevitably follows. ${ }^{81}$ Death itself is not depicted in these folios and, as noted, none of the martyrs is identified by name. What, then, was the purpose of depicting suffering rather than death, and binding these mute pages into the Sacramentary to illustrate the All Saints' Day liturgy? I believe Warmundus chose the martyrs' sufferings on their way to death for use in prayer and meditation. Each image inevitably will have invoked in him a train of memory - poems he had read, lives of the saints he had studied, sermons he had listened to - that would serve as the raw materials for his own sermons, addresses and prayers on the feast-day. In addition, the names and martyrdoms of the saints who were included in the Ivrea Martyrology of Adon will certainly have been familiar to all the clergy, Warmundus included, since they were recited, day by day, as a collective act of worship. And the presence of at least one tenth-century martyrology in the Chapter Library at

79 F. Lifshitz, The Name of the Saint, The Martyrology of Jerome and Access to the Sacred in Francia, 627-827 (Indiana, 2006), 4-5. This cult of the saint's name gained strength throughout the tenth century.

80 F. Crivelli, 'Le miniature del benedizionale di Ivrea, una scena di martirio ed alcune osservazioni sullo scriptorium warmundiano', in G.B. Trolese (ed.), Monastica et Humanistica: scritti in onore di Gregorio Penco, OSB (Cesena, 2003), 591-606, esp. pp. 599-603 and fig. 5. I thank Laura Marchiori for this reference.

81 See M. Roberts, Poetry and the Cult of Martyrs. The Liber Peristephanon of Prudentius (Ann Arbor, 1993), 70, for a discussion of this idea in the context of Prudentius's poetry. 


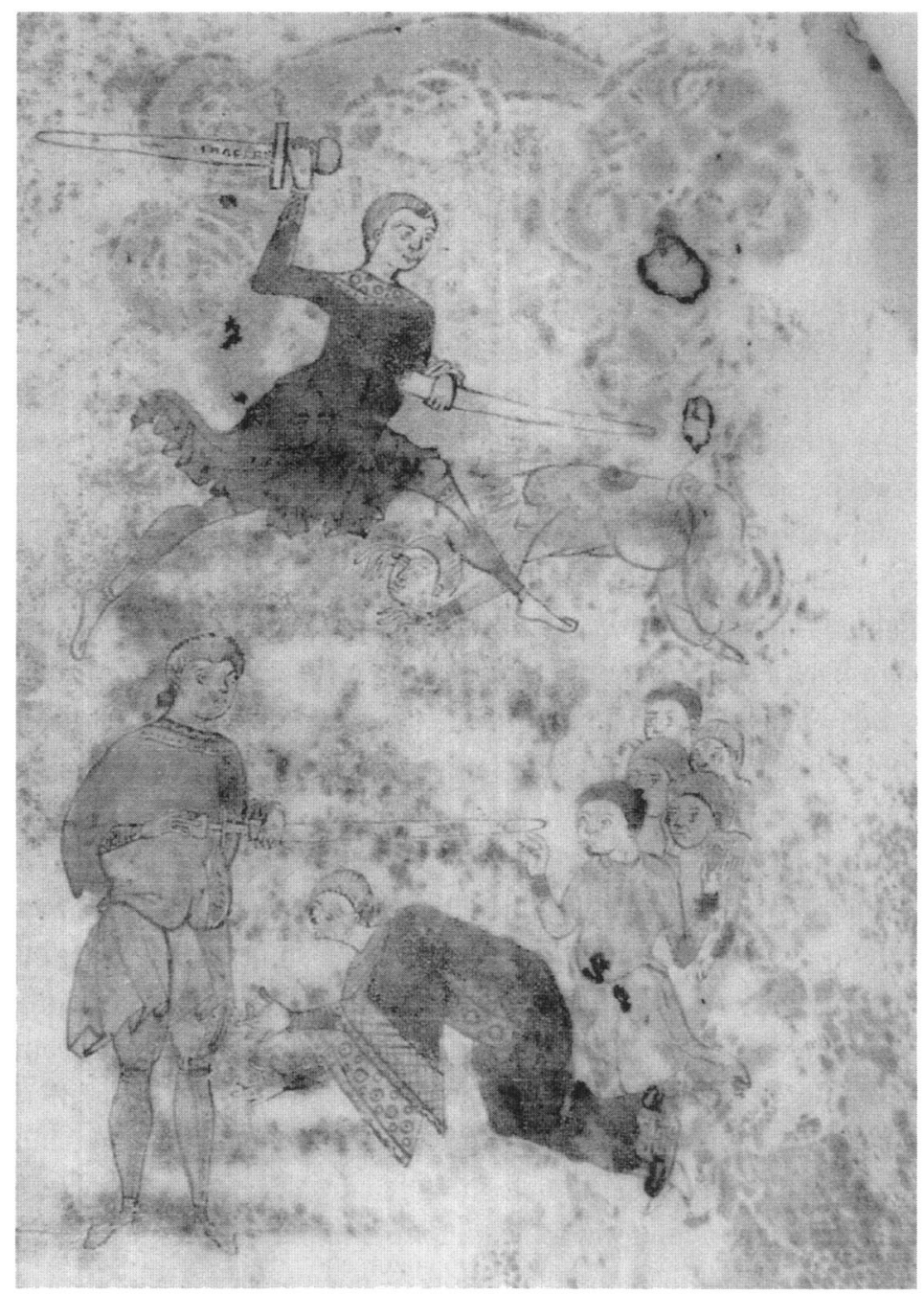

FIG. 15. Benedictional, Ivrea, Bibl. Cap. cod. XVIII (8), fol. 4l, Martyrdom of saints. (Reproduced courtesy of the Biblioteca Capitolare di Ivrea.)

Ivrea also suggests that the martyrs' sufferings were familiar to the bishop and his clergy, preparing them for contemplation of the All Saints' Day miniatures. It is even possible that the clergy or the scribes had seen actual torture themselves, since it was still used as punishment or to verify truth in the early Middle Ages. ${ }^{82}$

Some idea of an onlooker's reactions to images of torture and death again can be found in Ignatius's account of the anonymous martyrdom scenes at Patriarch Tarasius's church in

82 See E. Peters, Torture (New York/Oxford, 1985), 67-8, on the tortures used by the Romans and their survival into the early Middle Ages. 
Stenon - his viewers 'burst into warm tears', 'groan with compunction' and suffer 'contrition of heart. ${ }^{83}$ The pictures invoke compassion, admiration and faith, and Warmundus will surely have shared these feelings when he commissioned his All Saints' drawings.

One can suppose also that there were finite limits to the variants of torture that could be inflicted on the saints, ensuring that specific tortures were used as topoi over and over again in the early accounts of martyrdom. These tortures will have been applied also to the myriads of Christians who died for their faith, but whose names had already been lost by Warmundus's time. For this reason, he must have chosen not to name his All Saints' Day martyrs, so that they could symbolize anonymous martyrs 'whose names (only) God knows', as we read in an eighth-century wall-painting in Santa Maria Antiqua, Rome. ${ }^{84}$ Similarly, when Pope Paschal I brought the remains of the saints from the Roman catacombs into Santa Prassede, Rome, in 817 , an inscription was set up identifying 86 saints by name. Another 2,165 are stated to be 'known only to God', their names being 'written in the Book of Life. ${ }^{85}$ In much the same way, Ruth Leader-Newby has suggested that a silver reliquary casket in the Vatican Museums, the so-called 'Capsella Africana' from Numidia, conveys the 'generic idea of martyrdom' by means of an anonymous image of a young male saint, rather than identifying the relics of a specific individual. ${ }^{86}$

\section{Written sources: late antique Christian poetry}

Clearly, while it is probable that Warmundus, or his artist, had seen images in illustrated manuscripts or in monumental art of the tortures inflicted upon the early Christian martyrs, there are other possible sources for his All Saints' Day illustrations, and these sources of powerful imagery are literary. Libraries in the ninth and tenth centuries contained works of literature and poetry that surpassed the simple genre of saints' lives from legendaries and libelli, which probably were written by monks, nuns and clerics for their own use. Authors of Christian literature certainly included the Church Fathers, among them Gregory the Great, a few leaves of whose Dialogues have survived in the Ivrea Cathedral Library, and whose image occupies the place of honour in the Warmundus Sacramentary: the original frontispiece, folio $8 \mathrm{v}$ (FIG. 8). ${ }^{87}$ Gregory, though, did not dwell on the sufferings of the martyrs, preferring rather to emphasize

83 See Ephthymiadis (trans. and ed.), The Life of the Patriarch Tarasios (above, n. 71), 194-6; C. Barber, Figure and Likeness. On the Limits of Representation in Byzantine Iconoclasm (Princeton, 2002), ch. 6, esp. pp. 134-5.

84 'QUORUM NOMINA DEUS SCET'. See Jessop, 'Pictorial cycles of non-biblical saints' (above, n. 70), 241 and fig. 6, p. 243.

85 For the inscription, see U. Nilgen, 'Die grosse Reliquienschrift von Santa Prassede', Römische Quartalschrift 69 (1974), 7-29; Goodson, 'The relic translations of Paschal I' (above, n. 73), 136-7 ("Notes on the inscription in Santa Prassede'), and fig. 11.8.

86 R.E. Leader-Newby, Silver and Society in Late Antiquity. Functions and Meanings of Silver Plate in the Fourth to Seventh Centuries (Aldershot/Burlington, 2004), 105-7, fig. 2.28.

87 Mariaux, Warmond d'Ivrée (above, n. 1), 69, has determined on codicological grounds that folio 9 must have been the first folio of the original quire of the manuscript. 
their miracles and achievements. ${ }^{88}$ On the other hand, the late antique Christian poets who were nearer to the actual times of martyrdom, and more versed in the art of classical literature, had few inhibitions about describing these sufferings in horrific detail in their poetry. These poems reached a wide audience precisely because of their literary value as well as their sacred subject-matter. Prominent among these poets was Prudentius, whose Peristephanon Liber, Crowns of Martyrdom, a set of poems describing the passions and deaths of the early Christian martyrs, continued to be popular well into the early Middle Ages. As Michael Roberts wrote, "The Peristephanon poems continued to be valued as an expression of devotion to the martyrs long after the collapse of the imperial structure that provides the informing context for his view of the martyrs. ${ }^{89}$ Along the way, Prudentius's martyr poems were praised by the poet Venantius Fortunatus in the early sixth century, and were quoted or paraphrased in Gregory of Tours's Glory of the Martyrs later in that century. ${ }^{90}$ They were well known in the Carolingian period also. ${ }^{91}$

The continuing popularity of the Peristephanon into the period of the Warmundus Sacramentary can be gauged by the numbers of manuscripts containing Prudentius's poems that can be dated to the ninth and tenth centuries. Johannes Bergman listed 286 surviving medieval codices that include some or all of the Peristephanon poems. Sixty-nine of them date to the ninth or tenth centuries, and of these 43 include Peristephanon poems in whole or in part. ${ }^{92}$ The early tenthcentury manuscript, Bern, Burgerbibliothek, cod. 264, with its large selection of Prudentius's works, is one of the richest of these codices.

\section{Texts from the Peristephanon: source materials for the All Saints' Day folios?}

Let us attempt to match texts from Prudentius's poems with the graphic drawings of torture in Warmundus's All Saints' Day pictures. The poems describe the sufferings and deaths of individual martyrs, who are usually named and always identifiable. Prudentius has two ways of introducing the subject of torture. It may be described graphically by the judge to frighten the martyr into renouncing his faith, or it may be described as actually carried out by the executioners, with the same end in mind. In either case, torture is not usually the immediate cause of death.

88 Gregory the Great, Dialogues (trans. O.J. Zimmerman) (Fathers of the Church 39) (New York, 1959). See also n. 128 for the Dialogues fragment at Ivrea.

89 For the survival of Prudentius's Peristephanon Liber through the Middle Ages, see Roberts, Poetry and the Cult of Martyrs (above, n. 81), 8 .

90 For Gregory of Tours, see his Glory of the Martyrs, translated with an introduction by R. Van Dam (Liverpool, 1988), martyr stories 40, 42, 90 and 92, with sources in Prudentius's poems. See also P. Brown, The Cult of the Saints (Chicago, 1981), 83-4.

91 See E. Bartlett Vest, Prudentius in the Middle Ages (Ph.D. thesis, Harvard, 1932), 78-110, quoted by Roberts, Poetry and the Cult of Martyrs (above, n. 81), 8.

92 See J. Bergman, De Codicibus Prudentianis: Codices Enumerantur et Breviter Describuntur (Vienna, 1896), esp. pp. 8-9, in which he listed and dated the early medieval manuscripts that include whole or partial works by Prudentius. He gave full details of each of these. H. Woodruff, "The illustrated manuscripts of Prudentius', Art Studies 7 (1929), 33-79, discussed a single poem from Bern Burgerbibliothek, cod. 262: Pe 10, 'The declaration of St. Romanus the martyr against the pagans'. 
The individual images in the All Saints' miniatures can be matched well with Prudentius's texts, and vice versa. Roberts has pointed out that Prudentius chose catenae - chains - to epitomize the 'whole sequence of the martyrs' sufferings prior to death', 93 the 'scourgings, executioners, flames, tortures and chains' that had been enumerated by Pope Damasus in his epigram for the tomb of Saint Lawrence in the Agro Verano, Rome. ${ }^{94}$ Chains were the necessary prelude to any sequence of torture or execution, for it is obvious that a prisoner could not have been tortured or put to death without physical restraints. Chains are also much in evidence in the All Saints' folios. On folio $110 \mathrm{v}$ an unclothed victim is tethered to the floor by chains, while behind him a torturer tightens another chain around his abdomen (FIG. 12, lower left). ${ }^{95}$ Above, another naked victim is pegged and supported by an iron rest under his back, in such an agonizing position that water can be poured into his open mouth, drowning him literally as well as symbolically. Above again, a victim, also naked, is stretched out, tied to pegs, while a torturer prepares to rake him with a long-handled triple claw. This is the instrument that was believed to 'test the faith' of the martyr, and thus nicknamed the fidiculae. The last image of folio $110 \mathrm{v}$, on the bottom right, depicts a woman, the only female saint to be depicted. She submits to her right breast being twisted off by a thong while her arms are tied behind her back, (FIG. 12, lower right). The Sicilian Saint Agatha springs to mind. She is the archetypal saint to die from torture that included removal of her breasts. Her cult, recorded from early times by her inclusion in the Roman Canon of the Mass, continued into Warmundus's era and beyond, as we know from the illustrated manuscript in Paris of her passion (Paris, Bibliothèque Nationale, MS lat. 5594) that already has been mentioned as a rare survivor. ${ }^{96}$ The anonymous figure in folio $110 \mathrm{v}$ is one of only two of the eight saints to be partially clothed, in a long red skirt above which her breasts are bared. This probably follows customary iconography for Agatha, for the Paris manuscript also shows the saint with only her breasts bared.

Restraints are also in evidence on folio 111 , where a prisoner is shown with chains encircling his wrists, calves and ankles. These are being twisted and tightened by rods in the hands of two torturers. Below, a fully-clothed victim is held motionless on the floor by rod and chains to his back-stretched arms, as well as by the torturer's weight as he treads on him and twists off his tongue. By contrast, the upper part of folio $111 \mathrm{v}$ depicts a naked saint tied by cords to a post

93 Roberts, Poetry and the Cult of Martyrs (above, n. 81), 59. Even in Prudentius's first poem in the Peristephanon, he links the martyrs' experiences as '... [witnesses] who neither chains nor cruel death deterred' ('testibus quos nec catenae, dura nec mors terruit'): Pe I, 22.

94 Damasus, Epigrammata Damasiana, ed. A. Ferrua (Vatican City, 1942), 166-7, Epigram 33, 1-2, 'Verbera carnifices flammas tormenta catenas / Vincere Laurenti sola fides potuit / Haec Damasus cumulat supplex altaria donis / Martyris egregii suspiciens meritum' ('Scourgings, executioners, flames, tortures and chains, Lawrence was able to conquer all of them by faith alone'); Roberts, Poetry and the Cult of Martyrs (above, n. 81), 56.

95 Most of the major restraints are shown in the drawings as 'jiggled' lines: I interpret these as chains rather than ropes. Minor restraints, such as all those on wrists and ankles in FIGURE 12, are depicted by simple lines that may represent cords.

96 See Carrasco, 'An early illustrated manuscript of St. Agatha' (above, n. 67). Saint Calliopa, celebrated on 8 June in the Roman Martyrology, suffered this same torture before being beheaded. 
and shot full of arrows (FIG. 14, above). Is this Saint Sebastian, a renowned Roman martyr, celebrated on 20 January in the Gregorian liturgy and hence included in the Warmundus Sacramentary? A second naked victim on this folio is restrained face down by cords at the wrists and ankles while being sawn asunder by two executioners with a huge cross-cut saw.

Even where one of the torture scenes immediately brings to mind a well-known saint, such as Agatha or Sebastian, the lack of a specific name allows the viewer's mind to roam among the numerous others who suffered the same fate, and who also deserve honour. And it is here that Prudentius's poems allow us also to expand our vision of the saints' sufferings, so as to include some less well-known martyrs. This is because multiple texts can be found in the Peristephanon for all of the tortures portrayed in the All Saints' Day images.

First, let us consider the claw, a torture device designed to tear away the flesh and muscle from the underlying bones (FIG. 12, top). This device was first used by the Romans and continued in use through the Middle Ages. ${ }^{97}$ Three of the saints - Eulalia in Peristephanon 3, Vincent in Peristephanon 5 and Romanus in Peristephanon $10-{ }^{98}$ were subjected to the iron claw. Romanus prepares himself for the torture, "exposing his bare ribs to be cut away with the two-forked claws: ${ }^{99}$ again, the martyr eagerly assents to the test of his faith. In the case of Vincent, we read the judge's command, 'Then with cleaving strokes lay bare his ribs of their covering, so that his organs shall be exposed as they throb in the recesses of the wounds'. In addition, Prudentius's poem, 'A Hymn in Honour of the Eighteen Holy Martyrs of Saragossa' (Peristephanon 4), includes a lesser martyr's story, that of Encratis, whose side and breast were torn with the claw, right down to the heart itself, though she lived to describe her ordeal. ${ }^{100}$ All of these stories of the martyrs' sufferings are well illustrated by the raking image of folio 110v. Preparation for the rack is also described, when the judge ordered Romanus's body to be slung up on the rack to be torn, and to be stretched with hooks and cords. Furthermore, we read the judge's commands to the torturers of Vincent: 'Tie him with his arms behind and rack him upwards and downwards till the jonts of his bones in every limb are rent asunder with a crack'. ${ }^{101}$ I suggest that the upper scene on folio 111 illustrates both texts (FIG. 13).

The lower image on folio 111 shows the cutting or tearing out of a saint's tongue, a penalty inflicted on Romanus to silence him when he harangued the judge about the superiority of

97 Peters, Torture (above, n. 82); fidiculae, iron claws to 'test the faith'. See Hahn, 'Speaking without tongues' (above, n. 65), 168, n. 21.

98 Eulalia, Peristephanon 3, lines 131-4 'nec mora, carnifices gemini / iuncea pectora dilacerant / et latus ungula virgineum / pulsat utrimque et ad ossa secat' ('in a moment two executioners are tearing her slim breast, the claw striking her two girlish sides and cutting to the bone'). Vincent, Peristephanon 5, lines 113-16, 'posthinc hiulcis ictibus / nudate costanum abdita / ut per latebras vulnerum / iecor retectum palpitet' (see text after $\mathrm{n} .99$ for translation).

99 Peristephanon 10, 'Sancti Romani Martyris contra Gentiles Dicta', lines 72-3 'sponte nudas offerens / costas bisulcis exsecandas ungulis' (see text for translation). See also Roberts, Poetry and the Cult of Martyrs (above, n. 81), 62.

100 Peristephanon 4, lines 109. 44.

101 Vincent, Peristephanon 5, lines 109-12: 'vinctum retortis bracchiis / sursum ac deorsum extendite / conpago donec ossuum / divulsa membratim crepet'. 
the Christian faith over pagan religions (FIG. 13). ${ }^{102}$ The torture, however, failed to bring about its desired result, for by a miracle he continued to preach his faith even without a tongue. ${ }^{103}$ This torture and this miracle were to become part of the legendary passions of other medieval saints, whose vitae drew upon the topoi of the early Christian martyrs. The upper scene on the same folio could well illustrate Romanus's words to his judge: 'you think it is a wretched fate that I am hanging here stretched out, with my arms twisted behind me and my joints make noises as the tendons crack' ${ }^{104}$ The martyr is prepared for further assaults by the chains: first to be stretched out upon the ground and then perhaps to be stretched on the rack. The image and the poem could illustrate also the strappado, a torture where the victim would be raised from the ground and hung up from his backward-facing arms, as Romanus described.

We have seen already that the female figure in folio $110 \mathrm{v}$ could be the Sicilian Saint Agatha, whose story was well-known, as she is mentioned in the first eucharistic prayer, listed in all the martyrologies, and portrayed in an early illustrated life. ${ }^{105}$ Celebrated on 5 February, she is listed for that date in the Warmundus Sacramentary as well as in the Martyrology of Adon. But the story of the Saragossa martyr, Encratis, mentioned by Prudentius in association with torture by the hooks, here also gives further resonance to Agatha's suffering, for the torture was accompanied by the amputation of Encratis's breasts. "The barbarous tormentor tore all thy side, thy blood was shed, thy limbs mangled, thy breast cut off and thy bosom laid open down to the very heart', Prudentius wrote. ${ }^{106}$ Her festering wounds later caused her death and she was acclaimed a martyr in retrospect, and celebrated as such in the Roman Martyrology on 16 April.

Two references to Old Testament apocryphal figures who had become venerated as saints in the early Middle Ages also occur in the Peristephanon, where Prudentius's poems again resonate with the All Saints' Day miniatures. The first example is the Maccabees, who died around 168 BC, and were celebrated in the Roman calendar on 1 August. They refused to eat the meat of swine, which was forbidden in the Torah. Prudentius recounted in Peristephanon 5, "The Passion of Saint Vincent the Martyr', that among many tortures that the Maccabee brothers suffered individually, one of them had his tongue plucked out and offered to 'bloodthirsty birds. ${ }^{107}$ This punishment converges with the martyrdom of Romanus, who suffered the same fate, according to Prudentius. ${ }^{108}$ The lower scene on folio 111 (Frg. 13) graphically illustrates this torture.

102 Peristephanon 10, lines 123-390, 426-45, 459-545 and 562-70 for Romanus's discourse. The judge's reply, 573-85, condemns him to be burned on the pyre.

103 See also Hahn, 'Speaking without tongues' (above, n. 65), 176-8.

104 Peristephanon 10, lines 491-3, 'miserum putatis, quod retortis pendeo / extentus ulnis, quod revelluntur pedes, / conpago nervis quod sonat crepantibus'.

105 See Carrasco, 'An early illustrated manuscript of St. Agatha' (above, n. 67).

106 Peristephanon 4, lines 121-4: 'barbarus tortor latus omne carpsit/sanguis inpensus, lacerata membra. / pectus abscisa patuit papilla / corde sub ipso'.

107 Peristephanon 5, lines 533-4: 'num Maccabei martyris / linguam terannus erutam'. For the Maccabees, see B. Metzger (ed.), New Oxford Annotated Bible with the Apocrypha, including The Apocrypha of the Old Testament (with separate pagination) (Oxford, 1965/1977), 4 Maccabees, 309-29, esp. p. 321.

108 Peristephanon 5, lines 533-6. See also Peristephanon 10, lines 766-7, 'linguam tyrranus amputari iusserat / uni ex ephebis' ("The oppressor commanded the tongue of one of the lads [sic] to be cut out'). 
The second case where a figure from the All Saints' Day series resonates with both an Old Testament forerunner and a Christian saint is illustrated on folio $11 \mathrm{lv}$ (FIG. 14, below). The Old Testament individual, cited along with the Maccabee brothers in Peristephanon 5, is the prophet Isaiah, who is referred to there as 'sawn asunder. ${ }^{109}$ This tradition is described in an apocryphal source, The Martyrdom of Isaiah. ${ }^{110}$ King Manasseh condemned Isaiah to death because he claimed to have seen God and yet still lived, ${ }^{111}$ which was contrary to the Law's edict that no man could see God and live. ${ }^{112}$ Isaiah didn't cry out or weep 'but his lips spake with the Holy Spirit, until he was sawn in twain'. In the Christian era, the punishment of being sawn in two became a topos for the suffering and deaths of the martyrs, where it reappears, for example, in some medieval versions of the passion of Saint George. ${ }^{113}$ Indeed, many of these descriptions in the early hagiographic literature were borrowed again and again in subsequent lives and passions of the saints, and became standardized as topoi. ${ }^{114}$ As Cynthia Hahn has written of Romanus, the subject of Peristephanon 10, 'Prudentius is not merely telling the story of one unusual martyr, he is explicating the nature of all martyrs. The illustrator, in creating a pictorial retelling of the martyr's Passion, does so as well'. ${ }^{115}$ Thus, Prudentius's poems convey a universality that is akin to that of Warmundus's martyr figures as they undergo all varieties of torture. And just as the images represent both the original and any subsequent owners of the iconography, the intention of both poetry and illustration seems to be the same. This purpose is to dwell on the contrast between the fragility of the martyr's body, so easily destroyed by torture, and the integrity of his or her soul. In Peter Brown's memorable phrase, a 'psychodrame' is played out, through the display of terrible suffering, and reveals the curative power of the martyr's unscathed soul. ${ }^{116}$ It is the 'last great mystery of martyrdom', as Roberts put it, that even after death when the body and the spirit are finally separated, enough power remains in the earthly remains to combat 'the works of the devil and the secular world. ${ }^{117}$ This power, to help Christians in need, is generated by the sufferings of the martyr, which are elaborated by Prudentius almost to the exclusion of focus on the martyr's actual death. This concentration

109 Peristephanon 5, line 524: 'continet cum Maccabeis sectoque Esaiae proximum'. See also note b, below the text, for references to Isaiah's death in the Ascension of Isaiah, and in Jerome's Commentary on Isaiah.

110 R.H. Charles (ed.), The Apocrypha and Pseudepigrapha of the Old Testament, 2 vols (Oxford, 1913), I, II Maccabees (trans. and ed. J. Moffatt), 125-54. See also R.H. Charles, The Ascension of Isaiah (London, 1900), which covers approximately the same ground.

111 Isaiah 6.1-5.

112 Exodus 33.20.

113 See T.M. Weiner, Narrative Cycles of the Life of St George in Byzantine Art (Ph.D. thesis, New York University, 1977), for the reuse of earlier pictorial sources as 'improvised scenes'.

114 The Roman Martyrology celebrates on 22 April a sister of Saint Simeon, the consecrated virgin Tarbula, and her maid, who were 'both killed by being tied to stakes and sawn asunder'. See Dubois and Renaud, Le Martyrologie d'Adon (above, n. 77), 131, for the text.

115 Hahn, Portrayed on the Heart (above, n. 65), 84.

116 Brown, Cult of the Saints (above, n. 90), 82-3.

117 Roberts, Poetry of the Cult of Martyrs (above, n. 81), 67-8. 
on suffering is exactly what is depicted in Warmundus's All Saints' Day miniatures. Clearly the theme of both poetry and illustration is the same, and Prudentius's poems provide the key to understanding Warmundus's illustrations for All Saints' Day.

\section{WARMUNDUS'S ACTIVITIES BEYOND THE SCRIPTORIUM}

Luigi Magnani, the cleric who first studied this manuscript in detail in the early twentieth century, suggested that there is 'moral value' in the Warmundus drawings for All Saints' Day. In his words, 'the horrors of martyrdom were offset by the divine comfort, and the exaltation of the sacrifice by the rewards of heaven' ${ }^{118}$ His comments, which applied to the martyr himor herself, could also be seen in the context of the viewer: the Warmundus Sacramentary was not a public book, on display for all to get its message. It is quite small, at $22 \times 31 \mathrm{~cm}$, and also personal. Its use must have been reserved for the celebrant alone, the bishop of Ivrea, as well as his assistants and his successors. ${ }^{119}$ And it was its patron, Warmundus, bishop of Ivrea, who first hoped to share the rewards of heaven by studying and disseminating the martyrs' passions through this book, as well as by celebrating 'ultimate martyrdom' in the sacrifice of Christ in the Eucharist. ${ }^{120}$ Perhaps this is another clue as to the meaning of these disturbing pictures in the Sacramentary.

We can link Warmundus's choice of these graphic images also to his search for saintly patrons for Ivrea, for he sought the remains of local martyrs in the surrounding territory, both to protect the community and to sanctify his newly-rebuilt cathedral with their relics. Warmundus's building campaign, which is recorded in a contemporary inscription on the ambulatory wall, has been clarified by archaeologists. They discovered that the east end of the cathedral had been completely remodelled, and that a two-storey structure had been created in place of the simple wall enclosing a semicircular space outside the apse of the earlier church. ${ }^{121}$ A new hall-crypt now gave room for liturgical events and spacious burials, and above, an ambulatory for processions also featured squinches through which the faithful could view the central area of the crypt. ${ }^{122}$ This is where the saints' relics would have been housed, probably in the antique sarcophagus that was examined in the churchyard by Peroni in 1992, and now occupies the

118 Magnani, Le miniature del Sacramentario d'Ivrea; reprinted in Sacramentario (above, n. 7), 33.

119 I was told in the Chapter Library at Ivrea in 2005 that the Warmundus Sacramentary remained in use on the high altar for about 400 years.

120 I thank one of the anonymous reviewers for the Papers of the British School at Rome for this phrase.

121 See Peroni, 'Il ruolo della committenza vescovile' (above, n. 5), 265, plates 13-14, figs 21-3. The inscription runs: '+CONDIDIT HOC / DOMINO PRAE / SUL VVARMVN / DUS AB IMO'. See also McClendon, 'Church building in northern Italy' (above, n. 11), 223-6 on Ivrea cathedral, and nn. 32-3 on recent archaeological work there.

122 See Peroni, 'Il ruolo della committenza vescovile' (above, n. 5), plate 14, fig. 24, where small apertures through the masonry of the vault (squinches) are plainly visible. They are angled so as to view a central area, the possible site of the sarcophagus of Gaius Atecius Valerius, which is illustrated in Peroni's figures 32 and 33 . 
centre of the hall-crypt once more. ${ }^{123}$ Warmundus was successful in his search for martyrs, acquiring from other communities the remains of four saints - Bessus, Tegulus, Dalmaticus and Savinus - as protectors for Ivrea. ${ }^{124}$ Warmundus then added these martyrs' names to the list of saints invoked in the Canon of the Mass for Ivrea, on folio 16v of his Sacramentary. And once again, Prudentius sets a precedent in the Peristephanon. In the opening stanzas of his hymn to the martyrs of Saragossa, he celebrates a city

filled with glorious saints ... [that] has no fear of the destruction of this transitory world. When God comes, brandishing his brilliant right hand and resting on a redcolored cloud, to establish for the peoples of the world the scales of justice ... each city ... will hasten to meet Christ, carrying in baskets precious gifts. ${ }^{125}$

The gifts are the bones of their patron saints, the occasion, the Last Judgment.

Johannes Fried suggested that the building of many new churches in the so-called 'tenth-century awakening' was an expression of piety in expectation of the Last Judgment, which again, as in Prudentius's day, was thought by many people to be imminent. ${ }^{126}$ If so, this expectation would help to explain Warmundus's 30-year programme of activity in which he rebuilt his cathedral church, endowed it with fresh relics, and furnished it with illuminated altar books just in time for the year 1000. Buildings and their contents, whether relics, books or furnishings, would also help fashion the bishop's remembrance, as well as that of his cathedral and diocese, ${ }^{127}$ and this was certainly their destiny at Ivrea, though there is no evidence that Warmundus carried out these works with his own remembrance in mind.

It seems, though, that he believed passionately in the power of the saints to help and guide him. He took it upon himself to promote their cults, whether by bringing their remains into his cathedral for protection and veneration, or by instructing his scribes to depict their suffering in his Sacramentary, for use as a resource for both sermons and meditations. The resources of his cathedral library may well have contributed to his devotion to the saints, for it possessed a

123 This sarcophagus bears a sign of reuse: a poorly-repaired hole in the middle of the inscription, which suggests a portal for strips of cloth - brandea - that would be laid on the remains inside for subsequent use as relics. See Peroni, 'Il ruolo della committenza vescovile' (above, n. 5), 268, n. 54. By April 2005 the sarcophagus was in the centre of the crypt once more.

124 A relic of one of these saints (the arm of Dalmaticus, encased in silver) ('Item brachium sancti Dalmatii argenteum') is recorded in a mid-twelfth-century inventory of the cathedral's treasury. The record, Ivrea, Arch. Diocesano, perg. LXXVI, 16, EM-1.000.000/2, was transcribed by S. Castronovo, A. Quazza and C. Segre Montel, 'La miniatura', in G. Romano (ed.), Piemonte romanico (Turin, 1994), 392.

125 Peristephanon 4, lines 5-16, translated in Roberts, Poetry and the Cult of Martyrs (above, n. 81), 31.

126 J. Fried, 'Endzeiterwartung um die Jahrtausendwende', Deutsches Archiv für Erforschung des Mittelalters 45 (1989), 385-473 (translated by S. Denlinger and E. Peters as 'Awaiting the end of time around the turn of the year 1000', in R. Landes, A. Gow and D.C. Van Meter (eds), The Apocalyptic Year 1000, Religious Expectation and Social Change, 950-1050 (Oxford, 2003), 17-66, esp. pp. 23-4).

127 E. Palazzo, 'The image of the bishop in the Middle Ages', in Ott and Trumbore Jones (eds), The Bishop Reformed (above, n. 78), 87-91, esp. p. 89. 
ninth-century copy of the Dialogues of Pope Gregory the Great. ${ }^{128}$ Gregory wrote this around 593 , with the express aim of educating his congregation about the lives and miracles of Saint Benedict and other Italian saints. Hahn has identified the Dialogues as among the most important foundation volumes of the cult of the saints, along with Gregory of Tours's late sixth-century Life of the Fathers, Glory of the Confessors and Glory of the Martyrs. ${ }^{129}$

We should now consider the links between the All Saints' Day miniatures and other illustrations of death in Warmundus's Sacramentary. Can we reconcile his focus on the saints who, in folios $10 \mathrm{v}, 11$ and $1 \mathrm{lv}$, suffered in isolation, without the comfort of the clergy and the sacraments, with the ten miniatures that illustrate stages in the passage from life to death of an anonymous Christian of the tenth century? I refer again to the illustrations of the Agenda Mortuorum, which served the clergy who attended the dying Christian and prepared him for his departure from this world. ${ }^{130}$ The words of the liturgy and its prayers supported the dying man in his sickness; imposed suitable penance; directed the last rites and extreme unction; witnessed the preparation of his body for burial, blessed it, interred it, and comforted those left behind. Warmundus's ten miniatures are as unique as those of the All Saints' cycle, and stress the importance of the good Christian death, attended by the Church and the sacraments.

This abundance of unique illustrations of death in Warmundus's Sacramentary prompts the question whether these drawings, whether of death at home or of horrendous martyrdom, reveal a preoccupation on the part of the Sacramentary's patron, Warmundus. When the illustrations of the death of the most important holy personages and saints are added to the Agenda Mortuorum and the All Saints' Day images, it becomes clear that around one-third of the miniatures in Warmundus's Sacramentary are concerned with death. Is this entirely coincidental, or is it a reflection of internal or external factors in Warmundus's life? Internal factors would surely have included his advancing age, and his awareness that he might not have many more years to live. In support of his age, we can cite his holding of the Ivrea bishopric for almost 40 years, from around 966 to the early years of the new millennium. On the political level, too, these were perilous times. Warmundus was exiled from his see by his secular overlord, Arduin of Ivrea, from 996 to 998 . The bishop's life at this time was clearly in danger, for Arduin's supporters, on his orders, torched the cathedral at nearby Vercelli on 17 March 997, killing Bishop Peter and members of his clergy. In 1000, Otto III and Pope Sylvester II, acting together in order to 'reflect the symbiotic relationship between the spiritual and the secular worlds', ${ }^{131}$ excommunicated him, and, in addition, imposed a serious, lifetime penance on him for his sins. ${ }^{132}$

128 This survives as a fragment among the guard pages of a fourteenth-century missal, Ivrea, Bibl. Cap. $\operatorname{cod}$ XCV.

129 Hahn, Portrayed on the Heart (above, n. 65), 11-12.

130 See Sicard, La liturgie de la mort (above, n. 57) on the cycle of prayers illustrated in the Agenda Mortuorum; also Schmitt, La raison des gestes (above, n. 55), as well as Geary, Phantoms of Remembrance (above, n. 55), for the illustrations in the Sacramentary.

131 S. Hamilton, The Practice of Penance (Woodbridge, 2001), 2.

132 Hamilton, The Practice of Penance (above, n. 131), 1-2, 7, 8, 207-8. 
So Warmundus's books were created in a time of danger and uncertainty, when people at all levels of society were aware of millennial and apocalyptic thought. As an appointee of Otto I, serving the Ottonian dynasty as well as his diocese, Warmundus would have been aware of the beliefs and activities of the young emperor, Otto III. He was at court at least twice: first, at Easter 999, when Arduin was tried and condemned in Rome, and then in Pavia, on 9 July 1000 , when Otto gave Ivrea privileges against the Margrave. A further meeting with the emperor at Pavia in late 1001 is documented also. ${ }^{133}$ But a closer link with the court may have been forged when Leo, who had been at the centre of the court as Otto's palace chaplain in Rome, was appointed bishop of neighbouring Vercelli in 999. He was an expert in legal matters, both sacred and secular, and it was he who was charged by Otto with leading the case against Arduin. This case was successful, and the Ivrea diocesan lands were returned. The two bishops would have met during these negotiations, and it is likely that Warmundus became at least an occasional member of the circle around the emperor, a circle in which apocalyptic ideas were discussed, and where great manuscripts were on display. For example, although scholarship has been divided on the patronage of the Bamberg Apocalypse (Bamberg, Staatsbibliothek, MS Bibl. 140), the case for Otto III as patron in the last years of his reign, 1001-2, seems overwhelming, and has been argued convincingly by Henry Mayr-Harting. ${ }^{134}$ Otto's early interest in apocalyptic themes had been highlighted already by his choice of attire for his imperial coronation in Rome at the age of sixteen. This was a mantle entirely covered with scenes illustrating the entire Apocalypse in golden thread. ${ }^{135}$ It is clear from the manuscripts he commissioned that Otto's interest in apocalyptic themes continued throughout his last five years. Otto was also devoted to the cult of Saint Michael, and, as Daniel Callahan has put it, the spiritual activities of the last three years of his life [bear] ... witness to acute apocalyptic concerns. ${ }^{136}$ It is at that time that his belief in the imminent approach of the end of the world led him to the counsel of such holy men as Nilus of Rossano and Romuald of Camaldoli. The biographer of Saint Nilus, in a work dating from right after the saint's death at the start of the eleventh century, told how he commanded the young emperor in early 999 to undertake a barefoot penitential journey for remission of his sins. ${ }^{137}$ This pilgrimage was to the great

133 See R. Deshman, 'Otto III and the Warmund Sacramentary: a study in political theology', Zeitschrift für Kunstgeschichte 34 (1971), 1-20, esp. p. 16, n. 67.

134 Mayr-Harting, Ottonian Book Illumination (above, n. 20), II, ch. 1, "The Bamberg apocalyptic manuscripts of c. 1000', 11-56, esp. pp. 11-24, and Excursus I, 'The date of the Bamberg apocalypse', 215-28, esp. p. 215.

135 Fried, 'Endzeiterwartung um die Jahrtausendwende' (above, n. 126), 428, n. 199, quoting Miracula S. Alexii, Monumenta Germaniae Historica, SS, 4, p. 620, 'manthum, quo tegebatur coronatus, in quo omnis apocalypsis erat auro insignata'. See also Fried, 'Awaiting the end of time around the year 1000' (above, n. 126), 40-3, for numerous references to 'eschatological fervour' during Otto's reign.

136 D.F. Callahan, "The cult of St Michael the Archangel and the 'terrors of the year 1000", in Landes, Gow and Van Meter (eds), The Apocalyptic Year 1000 (above, n. 126), 181-204, esp. p. 185.

137 For the lives of the two saints, the Greek monk Saint Nilus, living in south Italy, and the Latin monk, Saint Romuald, see Hamilton, The Practice of Penance (above, n. 131), 174-7. See also Mayr-Harting, Ottonian Book Illumination (above, n. 20), I, 162-3. 
southern shrine of Saint Michael in the Gargano. The emperor's sin was the blinding and mutilation of John Philoganthus, his godfather, who had been set up as anti-pope by the rebel Crescentius during Otto's absence from Rome in 998. Otto's repentance was followed by a determination to spend three years in setting his kingdom to rights, so as to leave it to someone more capable of running it than he was. He would then divest himself of power and riches, and seek a monastery near Jerusalem where he could follow Christ. Otto's intentions were recorded by his companion, Bruno de Querfurt, on his last journey, which ended in his unexpected death from malaria in January $1002 .^{138}$

As bishop of his diocese, Warmundus certainly would have attended to the two primary duties of his position that had been defined by Gregory the Great in his Liber Regulae Pastoralis (Rules for Pastoral Care). Gregory regarded the bishop as a 'shepherd of souls' whose first duty was the pastoral care of his clergy and people. Contemplation was also required of him, and study of the beliefs, values and history of the Christian church. ${ }^{139}$ Warmundus also would have been aware of official church doctrine about the coming millennium, which was founded on Augustinian thought. Saint Augustine, who had discussed the Regnum Christi in his City of God, understood that any expectation that the world would come to an end after 1,000 years was to be understood as an allegory, and this became the "official' position of the Church. ${ }^{140}$ As a result, scholarly opinion has tended to dismiss the idea that the populace lived in abject fear of the end of the world in the period leading up to the year 1000. But, since the unlettered common people have not left written records, their fears were not recorded in writing. ${ }^{141}$ More recent research now allows that many ordinary people had at least been reached by preachers on the subject and were apprehensive about the times to come, especially since the late tenth century was a time of many natural disasters. ${ }^{142}$ So it seems clear that the possibility of the imminent arrival of the anti-Christ, followed by Christ's coming again in judgment, did give rise to an atmosphere

138 Bruno de Querfurt, Vita quinque fratrum (ed. R. Kade), in Monumenta Germaniae Historica, Scriptores XV (Hannover, 1888), 709-38, esp. pp. 720-1, ch. 3. See also Mariaux, Warmond d'lvrée (above, n. 1), 101-5.

139 Gregory I, Liber Regulae Pastoralis, c.590. See also n. 16, for particulars of the seventh-century manuscript of this work in Ivrea's Chapter Library.

140 Augustine, City of God 20.9.

141 For a balanced discussion of the positions for and against the presence of 'apocalyptic anxiety' around the millennium, based on the sources, see S. MacLean, 'Apocalypse and revolution: Europe around the year 1000', Early Medieval Europe 15 (1) (2007), 85-106, esp. pp. 96-106.

142 For arguments in favour of the idea that millennial anxiety was widespread, see R. Landes, "The fear of an apocalyptic year 1000: Augustinian historiography, medieval and modern', in Landes, Gow and Van Meter (eds), The Apocalyptic Year 1000 (above, n. 126), 243-70. See also his introduction in the same volume: "The terribles espoirs of 1000 and the tacit fears of 2000', 3-15, esp. pp. 6-11. See also M. Frasseto (ed.), The Year 1000. Religious and Social Response to the Tuming of the First Millennium (New York, 2002). Frasseto's 'Introduction' to the volume (pp. 1-7), and E. Peters, 'Mutations, adjustments, terrors, historians and the year 1000' (pp. 9-28) in the same volume, summarize the present position of historians on awareness of the approach of the year 1000. For the condition of the poor, see C. Taylor, 'The year 1000 and those who labored', in Frasseto (ed.), The Year 1000 (above), 187-236, esp. pp. 219-23, for evidence that a good many people who suffered anxiety as a result of their material experience of 'increased economic oppression, famine, disease and the results of bad weather - which were felt to be increasing in the late $10^{\text {th }}$ century, would have asked the perfectly intelligent question, 'why is this happening?'. The answer they received could well have been that it was the lead-up to the coming apocalypse'. 
that has been described as 'eschatological anxiety. ${ }^{143}$ This anxiety impinged on the thought of the whole period. ${ }^{144}$ It spread from the highest circles at court down through the lesser nobility and the populace in general, as we know from sermons dated around the year 1000 , designed for the lower clergy to preach to the working population, calming their fears and exhorting them to reform their lives. ${ }^{145}$

The widespread devotion to the cult of Saint Michael in the Ottonian court can be interpreted also in terms of his role as one's protector at the time of death. This devotion was certainly a feature of the Ottonian court and its emperor; but the cult of Saint Michael, which was expressed in the building of cult centres to him, also spread to the bishops of Piemonte. In two of Warmundus's codices, the Sacramentary and the Benedictional (Ivrea, Bibl. Cap. cod. XVIII (8)), we find evidence that, like his emperor, he was devoted to the Archangel Michael, who was especially venerated because he was believed to conduct the souls of dying Christians to God. He appears in the Sacramentary in a powerful half-page miniature (folio 108v; FIG. 16), that is accompanied by Warmundus's distich in the frame 'The enemy adversary falters, Michael, the soldier, triumphs. ${ }^{146}$ The Archangel is also pictured in one of only ten illustrations in the Benedictional (FIG. 17). ${ }^{147}$ Michael's inclusion in both these manuscripts also reflects the Ottonian world's widespread interest in Saint Michael and the role he would play in the approaching millennium. ${ }^{148}$ We read in the Apocalypse of Michael and his angels' victory over Satan, who was seen as a dragon with his own angelic army. ${ }^{149}$ It is not surprising that in perilous times, when the end of the world might well be imminent, people from all levels of society, churchmen as well as laity, and even including Warmundus himself, should take comfort in this prophecy that Satan would be defeated. The penitent emperor's journey to the shrine of Saint Michael in the Gargano certainly would not have gone unnoticed, and nor would the building of the great pilgrimage centre of San Michele della Chiusa, close to Ivrea in Piemonte. This complex was built on the summit of Monte Pirchiriano around 997, in response to a vision received by Saint John Vincentius, once a bishop and subsequently a hermit. In the vision Saint Michael appeared to John on the summit and ordered him to build a church there. By the year 999 a monastery had followed. ${ }^{150}$ Warmundus can hardly have been unaware of this important local centre of devotion to the Archangel Michael.

143 Callahan, 'The cult of St Michael the Archangel' (above, n. 136), 184, n. 20, where he has given references to the work of Focillon, Duby, Fried and others who have noticed this anxiety.

144 Fried, 'Endzeiterwartung um die Jahrtausendwende' (above, n. 126); Fried, 'Awaiting the end of time around the year 1000 ' (above, n. 126), 31-2.

145 For example, the Blickling homilies of Aelfric of Eynsham, in the English vernacular 'for the instruction at the time of the ending of this world. For the learned and unlearned alike. For preaching and teaching - the best means to prepare for the last days'. See Callahan, 'The cult of St Michael the Archangel' (above, n. 136), 190, nn. 88-90.

146 PARS ADVERSA LABAT / MICHAHELIS DEXTRA TRIUMPHAT.

147 Ivrea, Bibl. Cap. cod. XVIII (8), fol. 39.

148 Callahan, "The cult of St Michael the Archangel' (above, n. 136), 181-204.

149 Revelation 12.7-12.

150 Callahan, 'The cult of St Michael the Archangel' (above, n. 136), 186. 


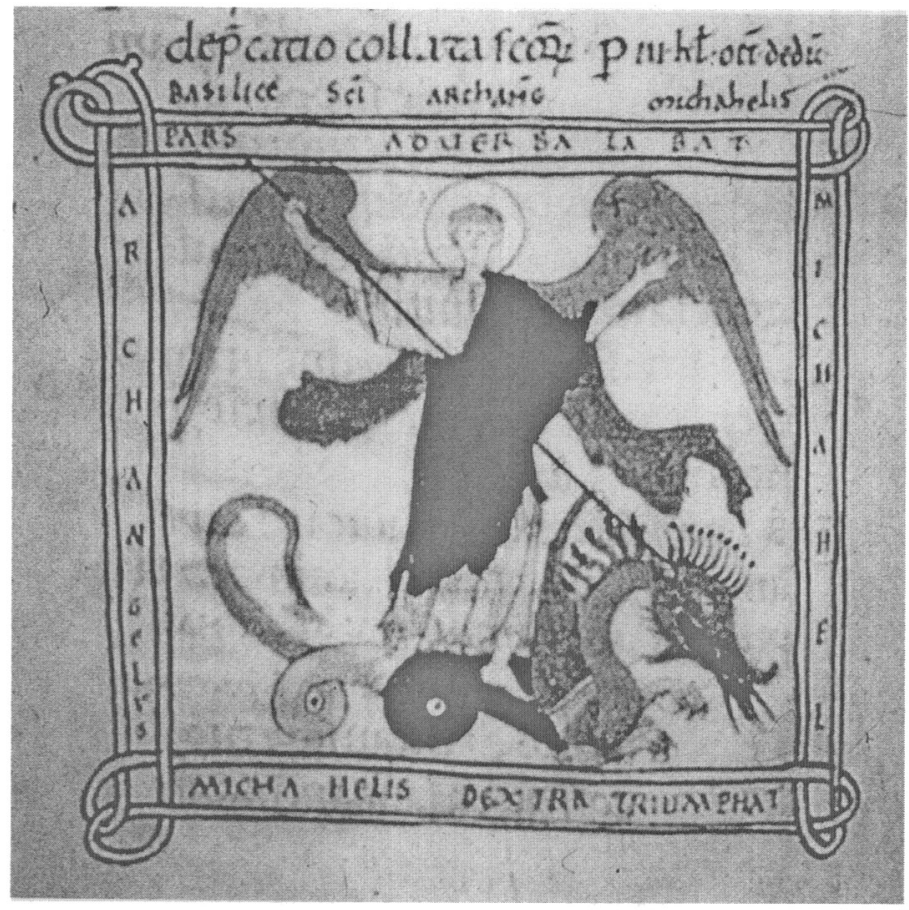

FIG. 16. Sacramentary of Warmundus, Ivrea, Bibl. Cap. cod. LXXXVI, fol. 108v, Archangel Michael. (Reproduced courtesy of the Biblioteca Capitolare di Ivrea.)

Environmental events also may have given Warmundus a sense of foreboding. We learn from the Five Books of the Histories of the monk Rodulfus Glaber of the portents that occurred in the lead-up to the millennium of the Incarnation. ${ }^{151}$ Looking back from a viewpoint that was perhaps 30 years after the year 1000, Glaber surely would have tapped into memories, his own and those of others, some of whom would have lived through these years. ${ }^{152}$ He listed many unusual disasters that took place during the $990 \mathrm{~s}$, and attributed them to the approach of the millennium. Among them was a major eruption of Vesuvius in the year 993 or 994, the 'seventh year' from the millennium, which gave rise to sulphurous fires and was accompanied by the ejection of rocks over distances of up to three miles. Around the same time, 'almost all the cities of Italy and Gaul were devastated by violent conflagrations, and Rome itself largely razed by fire'. ${ }^{153}$ It is clear that many of the events Glaber listed were based on fact. What may be questioned, however, is the accuracy of his dating and his interpretation of the events in terms of the millennium. Even

\footnotetext{
151 R. Glaber, Historiarum Libri Cinque, The Five Books of the Histories (ed. and trans. J. France) (Oxford, 1989).

152 On the subject of memory among the mostly illiterate populations of the central Middle Ages, see Geary, Phantoms of Remembrance (above, n. 55), 7-16, 'Creating the past', and 'A history of memory'.

153 Glaber, Histories (above, n. 151), book two, vii, 13, p. 73.
} 


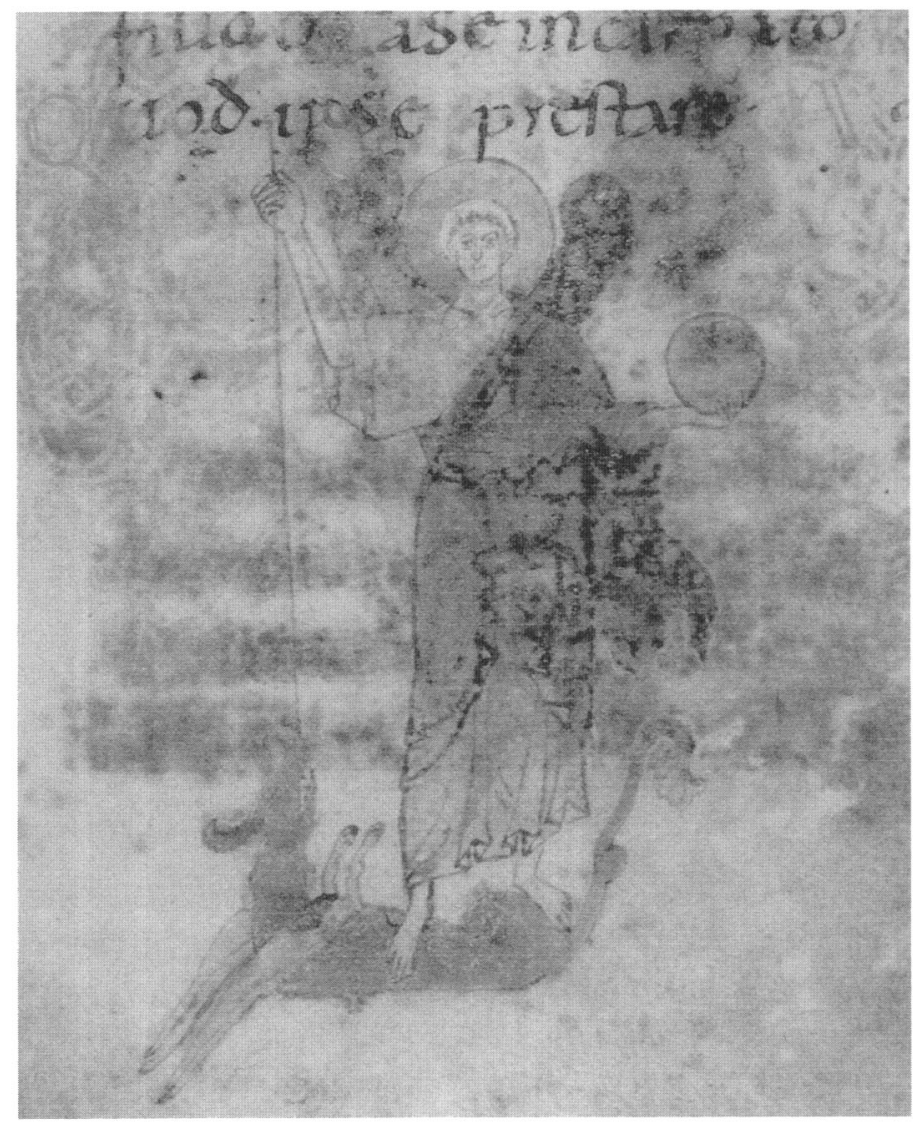

FIG. 17. Benedictional, Ivrea, Bibl. Cap. cod. XVIII (8), fol. 39, Archangel Michael. (Reproduced courtesy of the Biblioteca

Capitolare di Ivrea.)

so, they probably reflect the experiences and the memories of those who had lived through the intervening years. He told us that a great congregation rushed to confess their sins, sure that the end had come, and that disaster was thereby averted. Glaber continued by listing the names of many eminent men who had died. These were figures in both religious and secular life, from the pope down through 'the most noble persons of Italy'. Among them were all the most devout bishops in Gaul, as well as the upper echelons of the aristocracy from which they came. A terrible plague also attacked the people at this time. ${ }^{154}$ These events were followed by the death of the Duke of Burgundy, where a subsequent war of succession was heralded by the occurrence of a huge dragon in the sky, ${ }^{155}$ and followed by a five-year famine throughout the Roman world, so severe that Glaber described people being driven to cannibalism. Evidently these portents

154 Glaber, Histories (above, n. 151), book two, vii, 14, p. 77.

155 See B.E. Schaeffer, 'The astronomical situation around the year 1000', in Landes, Gow and Van Meter (eds), The Apocalyptic Year 1000 (above, n. 126), 329-35, esp. 'Inventory: 950-1050', pp. 330-3. 
were taken seriously by the general population, as well as by the monastic community, where Glaber was commissioned to write his Histories by his abbot at St Bénigne in Dijon, William of Volpiano.

Intimations of the perils to be suffered by the soul after death also had begun to surface at this period, and could well have increased Warmundus's interest in death and the afterlife. The formal inauguration by the Church of purgatory dates to the twelfth century. It was seen as a place where many imperfect souls - neither wholly bad nor totally good - would await judgment while undergoing painful retribution for sins committed on earth. There is evidence, though, that the existence of such a place was already being discussed at the turn of the eleventh century. ${ }^{156}$ For example, immediately after Warmundus's time, the Cluniac order inaugurated a 'Day of the Dead', All Souls' Day, on the day after All Saints' Day. ${ }^{157}$ All dead Christians were solemnly commemorated, and intercessions for them in the liturgy rapidly spread throughout Christendom. Such a development was the result of growing uncertainty about the fate of the soul in the afterlife, and the strong belief that the formalized prayers of the liturgy of death would lead to a favourable outcome, shortening the time of punishment in the purgatorial fires.

It is hard to avoid the conclusion that at all levels of society there was widespread belief that the end of the world was at hand, even if a fixed date was not known, as Mayr-Harting, among many others, argued convincingly. In his words,

the more emphatically churchmen stressed that men could never know the exact times and seasons ordained by God, the more strongly they often felt that they were living in the last days of the world. And for both Gregory the Great and the Venerable Bede (both of whom were familiar to educated Ottonians) the sureness of God's purposes combined with the uncertainty of his timing only heightened their sense of impending doom. ${ }^{158}$

This apprehension is certain to have afflicted Warmundus himself, leading him to prepare his soul, his church and his diocese for a favourable outcome on the day of Christ's return in judgement.

156 I am grateful to Lesley Pattinson for this suggestion.

157 J. Le Goff, The Birth of Purgatory (trans. A. Goldhammer) (Chicago, 1993).

158 See Mayr-Harting, Ottonian Book Illumination (above, n. 20), II 47-8, for development of this theme. The Ivrea library possesses early texts of the works of both Gregory I and of Bede. Among the ninth-century holdings are excerpts of the Dialogues of Gregory the Great in the 'foglia di guardia' of cod. XCV (100); his Moralia (cod. XC (47)), and, most ancient of all, his Liber Regulae Pastoralis (cod. I (I)). Holdings of Bede's works include a ninth-century codex of his sermons (cod. XXIV (36)), as well as both his De Natura Rerum and De Temporum Ratione (cod. XXXII (3)). See M. Ferrari, 'Libri e testi prima del mille', in Cracco (ed.), Storia della chiesa di Ivrea (above, n. 4), 511-35, esp. p. 525, for Gregory's works. For holdings of Bede's works, see Ferrari and Gavinelli, 'Elenco dei codici' (above, n. 17), 978-9, in the same volume. There is no record of Bede's Apocalypse having formed part of the Ivrea collection, though it may well have done so. Its text can be found in Migne, PL 93, cols 129-206. 
Warmundus's memory has persisted through the centuries in Ivrea, where his cult was sanctioned by the Church, and he was widely remembered as worthy of the title 'blessed'. ${ }^{159}$ Memory of his holiness certainly will have contributed to the survival of the many Warmundian manuscripts that are preserved in Ivrea's Chapter Library. These resources have enabled scholars to focus on his interests and achievements in unparalleled depth. It is not unreasonable to see in him a paradigm of ecclesiastical concerns in the late tenth century. His provision of illustrated books for the altar, as well as of towers and bells to call the clergy and congregation to worship, show him in the light of a diligent and energetic bishop, carrying out his duties. Added to that, he acquired the relics of four saints to protect his cathedral, his people and his diocese, Ivrea. He housed the saints in a new, strongly-built crypt - where they lay in a splendid classical sarcophagus - , and he built a new ambulatory with squinches for the processions of the faithful who wished to do them honour. These activities all would have been within the ambitions of an Ottonian bishop of the late tenth century. Warmundus was fortunate in having had the time to carry them out, and the means to finance them as well (though there is no record of how his numerous projects were funded, whether by personal wealth, which is not recorded, or by the resources of the diocesan lands). He also protected those lands and possessions to the best of his ability, taking his case to the emperor himself, and helping to secure their return from the Margrave Arduin. Although we cannot assume that Warmundus was anything but typical among the bishops of his time in carrying out his episcopal duties, there is no way of knowing whether he shared his interest in death, martyrdom and the Apocalypse with his fellow bishops. Since most other bishops of the period were neither patrons of manuscript art, writers of poetry, nor revered after their deaths as 'blessed', their individual interests and opinions have had fewer chances of survival. But we can assume that episcopal attitudes will have shifted around that time, when the assessment of the saintly life as the prime marker of sanctity changed to an emphasis on the manner in which the saint met his death. In this respect, Warmundus's deep interest in the cult of the saints may well have been shared with others in the episcopal hierarchy. ${ }^{160}$

\section{ACKNOWLEDGEMENTS}

I would like to thank the Librarian and staff of the Biblioteca Capitolare in Ivrea for a very pleasant visit and access to the manuscripts in April 2005, and especially for the chance to see the manuscript of the Warmundus Sacramentary itself.

159 For the history and bibliography of Warmundus's cult, see Magnani, Le miniature del sacramentario d'Ivrea (above, n. 15), 17-18.

160 I should like to draw readers' attention to Evan Gatti's important new paper, 'In a space between: Warmund of Ivrea and the problem of (Italian) Ottonian art', Peregrinations 3. (1) (2010), 8-48, which appeared when this article was in press. She discusses the Warmundus Sacramentary in terms of its patronage, its iconography and its historiography, analysing the work of Magnani, Deshman and Mariaux on the relative importance of episcopal and secular power in Ottonian lands south of the Alps, with special reference to Ivrea and its bishop, Warmundus. 
This work was carried out largely in the excellent library of the British School at Rome, while I was a resident there in 2004. I thank the librarian, Valerie Scott, and her assistants. I also very much appreciate the use of the facilities of the Hertziana Library, the Biblioteca Apostolica Vaticana, and the Warburg Library. I also thank the University of Victoria for its facilities and the use of the excellent inter-library loan service, and the University of Washington for forwarding books to the Whitely Center at Friday Harbor for me in successive summers.

Parts of the work have been presented at the 2004 meetings of the University Art Association of Canada, and the Conference of Medieval Art Historians of Canada, as well as in the History in Art Department of the University of Victoria. Readers for the Papers of the British School at Rome have given me invaluable advice, and certainly deserve my thanks. I much appreciate the trouble they have taken.

I also thank the many friends and colleagues with whom I have discussed the work over the last few years, especially Lesley Jessop, Janice Helland and Janis Elliott. I have been encouraged by the interest and help of all the members of my family, but must especially thank George Mackie for his expertise, his diligent reading and discussion of my manuscript, technical help, and his company on my 2005 trip to Ivrea. 